\title{
Mengaksikan Wacana Akuntansi Berbasis Pancasila Melalui Dekonstruksi Makna Stakeholders: Kritik atas Kapitalisme
}

\author{
Arrayyan Firdaus ${ }^{1}$, Minati Kartika Sari ${ }^{2}$, Ari Kamayanti ${ }^{3}$ \\ ',2 Politeknik Negeri Malang, Jl. Soekarno Hatta No. 9 Malang \\ ${ }^{3}$ Peneleh Research Institute, Pondok Indah Estate Blok B no 11 A Malang.
}

I N F O A R T I K E L

JEL Classification:

M41

M14

\section{Keywords:}

Pancasila, Stakeholders, Maskulin, Akuntansi Kapitalis, Pemahaman Akuntansi, Penginternalisasian Pancasila.

\section{$\begin{array}{lllllllll}A & B & S & T & R & A & C & T\end{array}$}

This research aims to analyze students' understanding about accounting, to portray accounting in Indonesia, and to reinterpret the meaning of stakeholders through Pancasila internalization. Bachelor students' understanding on the accounting interpretation and consciousness were interviewed as informants. The findings indicate that the three informants have different understanding about accounting because of different characters, education background, and experience. The three informants felt that accounting should not be interpreted as mere recording and reporting, but more. It is indicated that there is a growing consciousness of the informants to escape from the existing accounting as well as to significantly change accounting that is compatible with Pancasila. This article offers a form of action as a result of discussion with the informants in the form of reinterpretation of stakeholders that are more religious and humanist.

\section{A B S S T $\mathbf{T} \mathbf{R}$ A $\mathbf{K}$}

Penelitian ini bertujuan mengkaji pemahaman mahasiswa tentang akuntansi, memotret jati diri "keakuntansian" di Indonesia, dan kemudian mencoba untuk membangun pemaknaan ulang kata stakeholders melalui penginternalisasian Pancasila. Mahasiswa tingkat akhir program sarjana sebagai informan inti dieksplorasi lebih lanjut pemahaman dan kesadarannya tentang akuntansi melalui kegiatan wawancara secara mendalam. Temuan yang didapat mengindikasikan bahwa informan tersebut telah mampu memahami akuntansi dari berbagai sudut pandang yang berbeda sebagai akibat adanya perbedaan pada karakter pribadi, pendidikan, dan pengalaman mereka. Ketiga informan tersebut berpendapat, tidak seharusnya akuntansi dipahami sebatas pada pencatatan dan penyusunan laporan keuangan semata namun harus lebih daripada itu. Terindikasi adanya kesadaran informan untuk keluar dari akuntansi yang ada sekarang dan kemudian menginginkan perubahan yang signifikan pada sistem akuntansi yang senada dengan Pancasila. Artikel ini mengusulkan bentuk aksi wacana yang telah didiskusikan bersama informan dalam bentuk pemaknaan ulang kata stakeholders yang lebih agamis dan humanis. 
Hidup Mahasiswa, Hidup Mahasiswa, Hidup Mahasiswa, Hidup Rakyat Indonesia. Assalamualaikum. Apa kabar putra-putri calon akuntan terbaik Indonesia? Apa kabar pendidikan mata kuliah Pancasila mu?

Seberapa dekat akuntansimu dengan Pancasilamu? Atau sudahkah perguruan tinggimu menginternalisasikan nilai-nilai Pancasila kedalam dunia pendidikan akuntansi? Coba saya tebak, exactly belum sepenuhnya bukan. Its okay, berarti kita didalam panggung yang sama yakni panggung kapitalisme.

(Teriakan Arrayyan Firdaus pada saat Konferensi Nasional Akuntansi Pancasila Jilid Pertama, 2014)

\section{Pendahuluan}

Pada Konferensi Nasional Akuntansi Pancasila Jilid Pertama yang dilaksanakan oleh Ikatan Mahasiswa Akuntansi Indonesia Simpul Jawa Timur di STIE Asia Malang pada tanggal 1 Juni 2014 lalu, Pancasila sebagai ideologi negara disambut meriah oleh para peserta konferen. Pada acara tersebut terbentuk kesepakatan untuk memberikan ruang dan meletakkan Pancasila sebagai fondasi untuk mewujudkan the new accounting. Gairah berakuntansi dan berpancasila memang sudah mulai menggeliat di kalangan akademisi (lihat Setiawan dan Kamayanti, 2012; Ludigdo \& Kamayanti, 2012).

Secara implisit, kata "sepakat" pada salah satu kalimat yang tercantum pada paragraf sebelumnya, mencerminkan adanya kesadaran dari para peserta konferen bahwasanya proses pembelajaran yang mereka dapatkan di bangku kuliah memiliki simbol-simbolyang mengarahkan mereka untuk bertindak sebagai seseorang yang egois. Aktualisasinya mereka contohkan seperti pemaknaan simbol akun laba pada laporan keuangan yang mensyaratkan perusahaan untuk mengejar laba dengan rakusnya (Mulawarman, 2008).

Sudah sepatutnya pancasila dijadikan sebagai strategi kebudayaan bangsa, di mana pancasila disini diharapkan untuk dapat digunakan sebagai penjaga keseimbangan Indonesia ditengah hegemoni antar dua kutub pemecah bangsa yaitu tawaran ekonomi kapitalisme maupun sosialis dan tawaran atas dasar negara berdasarkan agama atau sekularisme. Melalui pernyataan Santiko (2012) ini pun kita dapat menarik benang merah bahwasanya pancasila adalah bentuk ideologi yang sangat lengkap. Pembuktiannya dapat terlihat melalui butir-butir pancasila yang bila kita cermati satu per satu didalamnya terkandung nilai spiritual, nilai kemanusian, nilai persatuan, nilai kebijaksanaan, dan nilai keadilan.

Hal ini tentu berbeda dengan nilai-nilai yang didistribusikan oleh ideologi yang berasal dari kaum barat yakni seperti kapitalisme. Kapitalisme mengajarkan kita untuk taat, patuh, dan tunduk pada nilai-nilai kombinasi dari egoistik dan materialistik yang kemudian menyatu dalam perekat utilitarianisme (Triyuwono, 2012). Sudah menjadi isu lama bahwa dalam dunia pendidikan akuntansi adanya pemahaman akuntansi harus disajikan dengan cara berpikir kapitalisme dan liberalisme yang merupakan wujud dari modernisme yang berciri reduksionis, mekanis, linier, dikotomis, dan materialistik (Bashir, 1986; Dhaouai, 1993; Ragab; 1993, dan Bakar, 1994).

Hines (1992) telah mengutarakan pendapatnya bahwa nilai-nilai kapitalisme telah merasuk pada jiwa akuntansi modern melalui ruh-ruh jahat egois, private, kuantitatif, dan materi sehingga melahirkan akuntansi bergender maskulin. Ruh-ruh jahat akuntansi bergender maskulin diatas sebenarnya ialah representasi dari sifat-sifat maskulin dewa Yang dan kemudian mencoba untuk memarginalkan atau sederhananya mereduksi sifat-sifat feminism dewa Yin yang altruistik, publik, kualitatif, dan spiritual (Lihat Roseau, 1992; Seidman, 1994; Lyotard, 1994; dan Rorty, 1994).

Akhirnya, akuntansi yang seharusnya berotasi pada keseimbangan orbit feminine-maskulin kini sedikit keluar dan menuju orbit egoistic (maskulin), yang kemudian terefleksi kedalam bentuk private cost/benefits bahkan kedalam orientasi penyajian laba kepada yang pihak yang paling berkepentingan yaitu shareholders. Padahal pemaknaan kata stakeholders (pemangku kepentingan) tidak hanya difokukan pada satu 
pihak saja yakni shareholders, namun juga kepada pemerintah, masyarakat sekitar, karyawan/buruh, dll. Bahkan melalui konsep syariah enterprise theory, Triyuwono (2012) menambahkan diperlukan adanya unsur lingkungan dan unsur ketuhanan dalam proes pemaknaan stakeholders.

Akibat yang paling parah ialah ketika sifat maskulin telah mampu membuat manusia meminggirkan unsur sosial dan unsur lingkungan sekaligus nilai-nilai transcendental atau nilainilai spiritual. Padahal, akuntabilitas kepada masyarakat dan lingkungan ialah perwujudan dari social and environmental accounting yang kemudian menimbulkan konsekuensi bahwa fokus dari pemikiran "keakuntansian" bukan hanya kepada konsep laba namun juga pertanggungjawaban kepada unsur-unsur sosial (Sukoharsono 2010). Artinya, secara harfiahnya sifat maskulin akuntansi akan mampu menjauhkan diri "seseorang akuntan" terhadap Tuhannya. Tidak heran jikalau, proses bersykur, proses mensucikan diri dengan mendistribusikan kebahagian melalui bantuan dana (dalam islam dikenal dengan zakat), dan proses mempertanggungjawabkan segala sesuatu kepada Tuhan seringkali hanya dijadikan sebagai wacana.

Artikel ini bertujuan melakukan proses penggalian dan pengembangan yang lebih lanjut untuk menghadirkan kembali keeksistensian konsep Pancasila dalam akuntansi. Melalui penginternalisasian falsafah Pancasila kedalam akuntansi diyakini mampu menutupi unsur maskulinitas yang berbasis pada kapitalisme yang masih berfokus pada konsep laba dan kapitalisasi modal. Akhirnya, dalam konteks yang lebih luas, pendekonstruksian ulang kata stakeholders berdasarkan perspektif falsafah Pancasila membantu setiap entitas sadar dan kemudian berusaha memenuhi aspek pertanggungjawabannya kepada Tuhan, manusia, dan alam berdasarkan unsur humanis.

\section{Tinjauan Pustaka}

\section{Pancasila Sebagai Falsafah dan Ideologi Negara}

Secara etimologis kata filsafat berasal dari bahasa arab yaitu falsafah, bahasa inggris yaitu philosophy, dan bahasa belanda yaitu philosophie. Semua istilah bahasa tersebut memiliki asal kata yang sama, yaitu kata bahasa yunani philosophia, yang mana disini terdiri dari dua kata yang sama, yaitu kata bahasa yunani philosophia, yang mana disini terdiri dari dua kata, yaitu philein yang berarti love (cinta) dan sophia yang berarti wisdom (kebijaksanaan atau kearifan). Jadi secara etimologis, filsafat dapat diartikan sebagai memikirkan dengan sungguhsungguh akan kebenaran atau hasrat yang besar (kegandrungan) terhadap pengetahuan yang benar.

Bagi bangsa Indonesia, filsafat atau pandangan hidup dan pandangan dunianya adalah pancasila. Pancasila merupakan hasil kristalisasi nilai-nilai yang dimiliki dan diyakini kebenarannya oleh bangsa indonesia. Pancasila sebagai perwujudan dasar negara dianggap baik dan bermakna sebagai pandangan hidup dan pandangan dunia bangsa indonesia. Dalam struktur kehidupan sosial bangsa indonesia, eksistensi (keberadaan) setiap manusia sebagai makhluk pribadi, makhluk sosial serta makhluk religius diakui, dihormati dan dijunjung tinggi martabat serta harga dirinya.

Pancasila yang terdiri dan tersusun atas lima sila pada hakikatnya merupakan sebuah sistem filsafat yang tidak terpisah satu sama lain. Sistem dapat dimaknai sebagai suatu kesatuan bagian-bagian yang saling berhubungan, saling bekerjasama untuk tujuan tertentu dan secara keseluruhan merupakan suatu kesatuan yang utuh (Kaelan, 2010).

Pancasila sebagai suatu sistem merupakan gambaran pancasila yang memiliki kesatuan bagian-bagian yang tercermin dalam sila-sila yang mempunyai fungsi masing-masing dan tidak dapat berdiri sendiri serta saling bertentangan, karena keseluruhan dari sila-sila tersebut merupakan suatu kesatuan yang bersifat organis. Membahas Pancasila sebagai sebuah sistem filsafat, berarti mengungkapkan pancasila sebagai sebuah sistem yang bulat dan utuh.

Pancasila adalah ideologi karena Pancasila adalah, sebagaimana yang dipahami 
(Kodhi dan Soejadi, 1989:47) tentang ideologi, cita-cita yang bersifat tetap, yang harus dicapai; sehingga cita-cita yang bersifat tetap itu sekaligus merupakan dasar, pandangan atau faham. Dari sejarah penggambarannya ditunjukkan, bahwa ideologi juga memainkan peran disimulasi lebihlebih dalam peran integrasi dan peran dominasi yang terkait dengan segi hirarki suatu organisasi sosial. Dimana disini, ideologi digambarkan sebagai sesuatu yang mencari kekuasaan dan membentuk suatu hubungan antara kekuasaan dan keyakinan dari para anggota-anggota kelompok sosial tersebut.

Namun demikian dalam kenyataannya, hubungan kekuasaan dengan sistem kekuasaan dalam kelompok sosial selalu berlangsung secara asimetris dikarenakan sering terjadinya defisit kepercayaan dari mereka atau ada kelebihan pretensi dari pihak yang berkuasa (Haryatmoko, 2008:6). Setiap kekuasaan menuntut lebih daripada keyakinan yang kita miliki. Untuk mendukung defisit kepercayaan itu, ideologi berperan menjadi sistem pembenaran dominasi, sehingga pada akhirnya disini, ideologi digambarkan sebagai sesuatu yang memiliki kecenderungan sifat doktriner.

Pancasila sebagai ideologi mencerminkan seperangkat nilai terpadu dalam kehidupan bangsa indonesia yang memiliki tata nilai yang dipergunakan sebagai acuan di dalam kehidupan bermasyarakat, berbangsa dan bernegara. Menurut Bakry (2010:180), pancasila sebagai suatu sistem filsafat praktis bagi bangsa Indonesia diyakini sebagai ideologi terbuka, bukan ideologi statik atau ideologi tertutup seperti komunis. Pancasila sebagai ideologi terbuka mengandung arti, bahwa pancasila yang dianggap selalu mampu untuk menyesuaikan dirinya dengan perkembangan zaman tanpa mengubah nilai dasarnya. Kemudian, pancasila sebagai suatu ideologi terbuka menurut Koento Wibisono dan Bakry (2010:182-184) memiliki ciri-ciri kekhususannya, yaitu bersifat realis, bersifat idealis dan bersifat fleksibel.

Pancasila sebagai ideologi bangsa indonesia bangsa indonesia mengandung makna bahwa nilai-nilai yang terkandung dalam ideologi pancasila itu menjadi cita- cita normatif bagi penyelenggaraan konsep kesejahteraan bersama. Pancasila sebagai sebuah ideologi, bukanlah sebuah "power base ideology" namum merupakan "cultural base ideology" sehingga dalam pengertiannya disini, ia merupakan satu bentukan nilai yang berasal dari akar kebudayaan bangsa Indonesia. Sebagai bagian dari akar kebudayaan bangsa indonesia tersebut, pancasila merupakan identitas 'index' (menunjukkan kemana arah bergerak), 'vindex' (memperingatkan kemungkinan-kemungkinan arah yang sesat) dan 'iudex' (yang menentukan apakah itu tepat atau tidak) (Kodhi dan Soejadi, 1989:68). Dengan kata lain, visi atau arahdari penyelenggaraan kehidupan menuju masyarakat yang sejahtera adalah terwujudnya kehidupan yang bedasar pada nilai ketuhanan, kemanusiaan, kesatuan, kerakyatan dan keadilan.

\section{Pendidikan Akuntansi di Indonesia}

Akuntansi merupakan produk yang dibangun dan berkembang dari nilai-nilai yang berkembang di masyarakat dimana akuntansi dan sistem akuntansi dikembangkan (Tinker, 1980 dan Sukoharsono, 2009:2,2010). Pendidikan akuntansi dan sistem pendidikan akuntansi negara "barat", dituturkan oleh Mulawarman (2008a:149,2012), diadopsi di Indonesia memang membawa nilai-nilai "sekularisasi" konsekuensi dengan ciri utama self-interest, menekankan bottom line laba dan hanya mengakui realitas yang tercandra (materialistik) yang terjadi hanya akan mengarahkan pendidikan akuntansi sebagai "perangkap hegemoni korporasi" (Mayper et al., 2005) serta mengisi pemahaman kepada peserta didik untuk memenuhi "kepentingan ekonomi (Armenic dan Craig, 2004) dan pemahaman untuk menikmati "kesejahteraan materi" (Triyuwono, 2006a:5). Ketika berbicara akuntansi, tidak ada kekuasaan Allah SWT disana, tidak ada nilai luhur indonesia dan nilai yang merekat erat dalam karakter Pendidikan akuntansi seharusnya dilakukan sesuai dengan UUD 1945 dan UU Sisdiknas2003, yaitu pendidikan yang menjadi media untuk menumbuhkan potensi holistik pesertadidik yang memiliki keseimbangan spiritual, mental, moral, kecerdasan dan 
ketrampilan (Hamzah, 2008).

Pendidikan akuntansi di Indonesia bahkan sudah sejak lama tidak memiliki "ruh" Pancasila di seluruh filosofi, konsep, teori, praktik, serta outcome profesionalitas akuntannya. Kalaupun Pancasila tetap diajarkan dijurusan Akuntansi di seluruh perguruan tinggi Indonesia, itupun hanyalah simbolisasi dan "basa-basi" politik kurikulum saja, sebagai pemanis dan bukannya sebagai kewajiban, apalagi kesadaran ber-Pancasila. Hal ini merupakan dampak kebijakannegara melalui Undang-Undang No. 20 tahun 2003 tentang Sistem Pendidikan Nasional yang tidak memberikan kepastian dan kewajiban pentingnya Pancasila sebagai "ruh" pendidikan akuntansi. Setiap diri manusia harus menyadari bahwa dirinya merupakan bagian dari sesuatu yang lebih besar daripada dirinya sendiri. Setiap diri yang sadar mempunyai kewajiban untuk membangun peradaban yang lebih baik, karena dirinya adalah bagian dari masyarakat, wujud, eksistensi dan pengetahuan yang kesemuanya itu direalisasikan dalam tindakan (Kamayanti, 2012:7).

Pandangan pembelajaran yang dijalankan di Indonesiapun menurut Mulawarman (2012) masih berdasarkan konsepsi pembelajaran reproductive view of learning dan kurang menggunakan konsep constructive view of learning (Byrne dan Flood 2004). Pandangan pembelajaransepertiinimenyebabkanmaha-siswa tidak dapat menyelesaikan masalah - masalah kontekstual dan selaluberubah-ubah. Dampaknya, pendidikan akuntansi tidak melihat pentingnya membekali mahasiswa menjadi pionir-pionir pemberdayaan masyarakat. Mereka menjadi pribadi-pribadi yang asing dengan lingkungannya. Asing dengan sistem Ekonomi Kerakyatan sebagai simbol Ekonomi Pancasila. Pendidikan akuntan lebih akrab dengan dunia bisnis yang bergelimang peredaran dana ratusan miliar per hari di pasar modal. Oleh karena itu, pendidikan Akuntansi harus disucikan. Mulawarman menamakan proses penyucian tersebut dengan tazkiyah. Melalui tazkiyah, Akuntansi akan mengembalikan cintanya kembali pada Tuhan, atau hyperlove. Hasilnya, akan ada perubahan dari cinta yang egoistis ke arah cinta melebihi keseluruhan (hyper) dan sebuah penguatan nilai tambah seperti pembebasan dari hegemoni korporasi. Untuk mengakomodasi pembebasan tersebut, Mulawarman menambahkan konsep pembelajaran oleh Byrne dan Flood (2004) dengan kesadaran diri, proses intuitif dan kepatuhan melalui jalan spiritual. Konsep yang diperluas ini diperkenalkan sebagai Hyperview ofLearning (HOL). HOL merupakan proses pembelajaran yang saling terjalin berkelindan satusama lain, berorientasi pada penggalian terstruktur, integral dan atau sinergis berkenan aspek kecerdesan akal/kuantitatif (guna meningkatkan pengetahuan memorization, dan akuisisi fakta serta prosedur yang dapat dipergunakan dalam praktik), dan integratif/kualitatif (abstraksi makna dan proses interpretasi yang bertujuan memahami realitas) melalui proses mental-spiritual (kesadaran diri melalui proses intuitif dan aktivitas ketundukan spiritual) sebagai proses pembebasan sekaligus pencerahan. Tujuan akhirnya, diharapkan mahasiswa mampu menjadi diri seutuhnya, change as a person dan memiliki pengetahuan akuntansi yang selalu melakukan proses pencerahan dan emansipasi di lingkungan sekitarnya.

HOL telah diimplementasikan melalui pemurnian kembali menjadi refined Hyperview of Learning (rHOL) (Kamayanti and Mulawarman, 2009a). Dalam rHOL terdapat perubahan kesadaran pada pendidik Akuntansi dari kesadaran naïf menjadi kesadaran kritis, dan ini menjadi sangat penting. Menurut Kamayanti (2012), kesadaran yang utuh adalah ketika individu dapat menyeimbangkan kesadaran rasional (rational consciousness), kesadaran kritis (criticalconsciousness), kesadaran intuitif (intuitive consciousness), hingga mencapai kesadaran spiritual (spiritual consciousness). Ketika individu tersebut meraih pusatnya, yaitu kesadaran spiritual, maka keempat kesadaran tersebut menjadi seimbang membentuk suatu kesadaran diri (self consciousness). Ketika kesadaran diri telah terbentuk, individu akan menyadari hubungan (interkoneksi) dirinya dengan Penciptanya (God). Ini akan menggiring sebuah diri berubah menjadi diri yang lain. 


\section{Akuntansi Bergender Maskulin vs Akuntansi Bergender Feminim dan Konsekuensinya pada Pendidikan Akuntansi}

Dominasi maskulinitas dalam konteks sosial budaya telah mengakar begitu lama, yang menurut Bourdieu (2010), terjadi karena suatu proses reproduksi dan dianggap menjadi suatu kebenaran (doxa). Tak terkecuali dalam konteks keilmuan akuntansi. Akuntansi dalam segala aspeknya, mulai dari pendidikan secara teoritisnya hingga praksisnya di lapangan profesionalitasnya, hingga hari ini, masih menampakkan wajah maskulinitas yang mendominasi.

Salah satu ciri maskulinitas pada pendidikan akuntansi adalah terlalu besarnya fokus pada rasionalitas (James, 2008; Kamayanti, 2011). Hal ini juga didasarkan pada pengembangan keilmuan akuntansi masih didominasi paradigma positivis, yang ruhnya merupakan rasionalisme. Bukti lain adalah Statement of Financial Accounting Concept (SFAC) No. 1 paragraph 34 yang juga memunculkan terma rasionalitas. Konsekuensi logis dari dominasi maskulinitas ini adalah bahwa: pertama, paradigma positivis menuntun para akademisi akuntansi mengembangkan keilmuan akuntansi sebatas untuk tujuan terbatas yaitu to explain dan to predict praktik akuntansi. Rasionalisme meyakini bahwa kebenaran (the truth) dan pengetahuan (knowledge) diperoleh dari proses pengindraan serta proses berpikir deduktif(Rasyidin dalam Tim Pengembang Pendidikan, 2007:25). Paradigma positivis memiliki asumsi bahwa pengetahuan "hanya" dapat dibangun dari "..hypotheticodeductive account of scientific explanation" (Chua, 1986:611). Dalam asumsi paradigma ini ,“...realitas empiris adalah eksternal dan objektif terhadap subjek. Human beings dicirikan sebagai passive objects, bukan sebagai perekayasa realitas sosial." Dengan demikian, rasionalisme pada basis paradigma positivis dalam pengembangan ilmu akuntansi ini sangat mengagungkan objektivitas dan keterpisahan/keterlepasan antara objek dan subjek (detachment).

Konsekuensi logis kedua, sebagaimana dikutipPowellandDimaggio(1997:63)MaxWeber menyatakan bahwa rasionalisme menjadi penjara (ironcage) yang mengekang unsur kemanusiaan. Hal ini memiliki pengaruh pada etika akuntan. Misalnya, penggunaan etika profesi akuntan yang didominasi nuansa maskulin akan menekankan pada keterpisahan/keterlepasan (detachment) objektivitas, impersonaliti dan otonomi individual berlebih (Reiter, 2007). Pada saat kondisi ini yang terjadi, etika akan mengesampingkan beberapa aspek femininitas (sebagai lawan maskulinitas) seperti responsiveness, cooperativeness, intuisi, spiritualitas dan religi. Dalam terminologi ajaran Tao, maskulinitas ini merupakan karakter "Yang", sedangkan feminitas lekat dengan "Ying". Tao mengajarkan agar Yin dan Yang berada dalam pola yang seimbang agar tercipta harmoni. Pada saat Yang lebih mendominasi atas Yin, kondisi ini dapat menyebabkan problematika sistemik (Capra, 2007: 9).

Tidak hanya pada substansi dan proses pendidikan. Maskulinitas juga tercermin pada pengelolaan institusi pendidikan. Maskulinitas dalampendidikan akuntansi juga terletak pada kebutuhan untuk mendominasi (need of domination), sebagaimana disentil dalam lagu gubahan Taufik Ismaildi awal tulisan ini. Pada titik ini, ikhtiar pendominasian merupakan hasilkolaborasi antara beberapa kuasa (power) institusional yang saling berkelindan: institusi pendidikan, pemerintah, ikatan profesi dan pasar (market). Di bawah kuasa institusi pendidikan, siswa dipaksa untuk menerima bahwa universitas atau sekolah merupakan satu-satunya tempat untuk belajar dan tindakan belajar (actoflearning) tersebut adalah resulta tindakan pengajaran (act of teaching) (Illich, 2008: 40-58). Dalam konteks penelitian tentang pendidikan akuntansi, Tietz (2007) memberikan bukti empiris. Dia dengan gagah berani mengatakan bahwa maskulinitas begitu kuat menjelma dalam pendidikan akuntansi. Penelitiannya menunjukkan bahwa dalam mayoritas buku teks akuntansi, perempuan masih menduduki strata yang inferior di hadapanpria. Stereotyping atas posisi perempuan ini lalu juga terkuatkan argumentasinya melalui peran perempuan dalam profesi akuntansi yang relatif termarjinalkan. James (2008) menegaskan hal yang serupa, tujuan pendidikan akuntansi 
menitik beratkan pada rasionalisme ekonomi yang didesain untuk memenuhi kebutuhan bisnis yang berkembang. Dalam bahasa yang senada, Triyuwono (2010) berujar, aspek rasionalitas (unsure maskulin) lebih mendapatkan sentuhan dibandingkan aspek emosional, mental dan spiritualnya (unsur feminin) pada pendidikan akuntansi.

Berpijak dari pendapat Tietz (2007), James (2008), Triyuwono (2010) diatas, juga Mulawarman (2006, 2007) serta Kamayanti (2010) jelaslah sudah bahwa pendidikan akuntansi penuh sesak dengan karakter maskulinitas yang mendominasi. Maskulinitas ini mewujud mulai dari konten keilmuanakuntansi itu sendiri, hingga juga menyentuh metode pembelajaran yang direproduksi oleh institusi pendidikan melalui para pendidiknya. Efek tak terhindarkan berikutnya adalah keilmuan akuntansi dan pendidikan akuntansi yang berwatak maskulin ini tentu saja akan melahirkan produk-produk akuntan yang juga berwatak sama dengan yang diajarkan. Prototipe yang dihasilkan pendidikan akuntansi yang lebih menitik beratkan maskulinitas ini akan menghasilkan konsekuensi logis ketiga yang berwujud calon-calon akuntan yang bercirikan rasionalis, antroposentris/egois apatis, tidak peka keadaan sekitar (impersonality), objektif dan kering akan nilai-nilai spiritualitas [(Mulawarman, 2006, 2007), Triyuwono (2010), Kamayanti(2010)].

Menurut Soedarsono (2009) dalam Eka Sari (2012) pancasila telah terbukti ampuh dan berfungsi sebagai ideologi melalui sembilan fungsi, yaitu (1) Pancasila sebagai dasar negara.

(2) Pancasila sebagai pandangan hidup bangsa.

(3) Pancasila sebagai kepribadian bangsa. (4) Pancasila sebagai jiwa bangsa. (5) Tujuan yang akan dicapai bangsa. (6) Pancasila perjanjian luhur bangsa. (7) Pancasila sebagai asas kehidupan bangsa. (8) Pancasila sebagai moral pembangunan bangsa. (9) Pancasila sebagai pengamalan pembangunan bangsa. Pembangunan kembali karakter bangsa cukup mendesak untuk dilakukan mengingat bangsa kita saat ini sedang mengalami degradasi moral. Dengan membangun karakter akan dapat diperoleh jiwa yang kuat, visis yang jauh ke depan dan jernih dan mendapat inspirasi dalam ambisi atau segenap usaha dan upaya kita sehingga sukses sejati bisa diraih (Keller seperti yang dikutip Soedarsono, 2009). Oleh karena itu dirasa perlu untuk mengintegrasikan Pancasila dalam pendidikan akuntansi. Dengan internalisasi nilai-nilai Pancasila terhadap akuntansi diharapkan akan tercipta akuntan yang terampil di bidang akuntansi namun berkarakter Pancasila.

\section{Pengertian Stakeholders}

Stakeholders didefinisikan sebagai pihakpihak yang dapat memengaruhi atau dipengaruhi (menerima dampak) oleh keputusan yang diambil (Freeman, 1984) atau dapat pula didefinisikan sebagai orang, kelompok atau lembaga yang memiliki perhatian dan/atau dapat mempengaruhi hasil suatu kegiatan (Salam dan Noguchi, 2006; Kusumedi dan Bisjoe, 2010). Dengan demikian dapat disimpulkan bahwa stakeholders adalah semua pihak baik secara individu maupun kelompok yang dapat dipengaruhi dan/atau mempengaruhi pengambilan keputusan serta pencapaian tujuan suatu kegiatan.

Berdasarkan keterkaitannya terhadap suatu keputusan atau suatu kegiatan, Townsley (1998) kemudian membedakan stakeholders menjadi dua yaitu stakeholders primer dan stakeholders sekunder. Stakeholders primer adalah pihak yang memiliki kepentingan langsung terhadap suatu sumberdaya, baik sebagai mata pencaharian ataupun terlibat langsung dalam eksploitasi. Stakeholders ini oleh Yang, et al., (2010) disebut juga sebagai stakeholders kunci (key stakeholders). Stakeholders sekunder adalah pihak yang memiliki minat/kepentingan secara tidak langsung, atau pihak yang tergantung pada sebagian kekayaan atau bisnis yang dihasilkan oleh sumber daya.

Berbeda pandangan dengan Freeman (1984) tentang pemaknaan kata "stakeholders" yang hanya mengartikannya dengan unsur manusia saja, melalui konsep syariah enterprise theory(SET) nya, Triyuwono (2012) mencoba untuk memaknai kata "stakeholders" dengan memasukkan unsur tambahan yakni unsur Tuhan 
dan unsur alam. Konsekuensinya ialah adanya nilai keseimbangan bahwa suatu entitas nantinya tidak hanya peduli kepada kepentingan individu (dalam hal ini pemegang saham), tetapi juga pihak-pihak lainnya. Alhasil, melalui pemaknaan seperti ini diharapkan segala sesuatu yang berbau "keakuntasian" dibangun berdasarkan pondasi tata-aturan atau hukum-hukum Tuhan.

Stakeholders kedua menurut (SET) ialah manusia. Disini dibedakan menjadi dua cluster besar yakni direct stakeholders dan indirect stakeholders. Direct stakeholders diartikan sebagai pihak-pihak yang secara langsung berkontribusi terhadap perusahaan atau entitas baik dari segi keuangan maupun non keuangan. Karena telah memberikan kontribusi, maka para direct stakeholders ini pun berhak mendapatkan kesejahteraan dari perusahaan atau entitas tersebut. Kemudian, indirect stakeholders ialah pihak-pihak yang sama sekali tidak memberikan kontribusi terhadap perusahaan atau entitas tersebut. Namun, walaupun tidak memberikan kontribusi, secara syariah mereka juga berhak mendapatkan kesejahteraan dari suatu perusahaan atau entitas.

Stakeholders yang terakhir menurut Triyuwono (2012) ialah alam. Alam dapat diartikan sebagai pihak yang turut memberikan kontribusi pada suatu perusahaan atau entitas sebagaimana dengan Tuhan dan manusia. Hal ini dapat ditunjukkan bahwa suatu perusahaan secara fisik berdiri tegak diatas bumi (alam), dan kemudian untuk menunjang kegiatan operasionalnya perusahaan juga membutuhkan bahan baku yang pastinya berasal dari alam. Maka daripada itu, sudah saatnya alam juga turut mendapatkan pendistribusian kesejahteraan dari perusahaan melalui program pelestarian alam, pencegahan pencemaran, dll.

Akhirnya melalui konsep SET dalam memaknai kata stakeholders, kita dapat menyimpulkan bahwasanya Tuhan haruslah menjadi yang utama dalam proses pertanggung-jawaban sebuah perusahaan atau entitas dikarenakan Tuhanlah yang menjadi tempat kembalinya manusia dana alam semesta. Oleh karena itu, sudah sepantasnya manusia sebagai khalifah di muka bumi, untuk turut dan patuh akan tata aturan atau hukum-hukum Tuhan. Melalui cara inilah, manusia akan menyadari bagaimana cara bersyukur dan kembali kepada Tuhannya guna memperoleh jiwa yang tenang. Tentunya hal ini juga membutuhkan penyatuan diri antara sesama manusia dengan alam sekaligus dengan aturanaturan yang telah melekat didalamnya.

\section{Metode}

Penelitian mengenai keterkaitan dan dekonstruksi pemaknaan kata "stakeholders" ini bersandar pada paradigma kritis sebagai payung penelitian. Penelitian kualitatif ini menekankan pada subjektifitas dan pengungkapan dari pengalaman para informan. Penelitian ini menggunakan teknik analisis data melalui empat tahap. Tahapan pertama mendeskripsikan fenomena dari hasil wawancara yang telah direkam. Transkrip wawancara mengidentifikasi dan menjelaskan kualitas dari pengalaman dan kesadaran informan. Tahapan kedua, mengidentifikasi tema yang muncul dari deskripsi pada tahap pertama. Tahapan ketiga, pengembangan relasi kesadaran dan pengalaman. Tahapan keempat, menginsersikan Pancasila sebagai pemaknaan ulang stakeholders.

Akhirnya, adapun tujuan yang hendak dicapai melalui penelitian ini ialah: 1) terciptanya dialektika akuntansi yang terus berkembang dan terus berproses; 2) pengetahuan akuntansi makin kaya dengan pemikiran; dan akhirnya 3) praktik akuntansi dimasa mendatang diharapkan akan makin bermakna dikarenakan adanya proses pembaharuan pemaknaan pada sesuatu simbol "keakuntasian". Tujuan ketiga pada pernyataan sebelumnya adalah point penting dari tujuan penelitian ini. Hal ini menggambarkan adanya keinginan penulis untuk berusaha menyadarkan para pihak-pihak yang berkecimpungan pada pembuatan pelaporan keuangan untuk melihat sisi lain dari pemaknaan kata "stakeholders" untuk menemukan makna yang lebih bersahaja yang kemudian sesuai dengan kepribadian bangsa Indonesia yang dalam hal ini dikerucutkan melalui perspektif falsafah Pancasila. Salampessy 
(2012:37) berpendapat bahwa Pancasila mengajarkan bangsa Indonesia untuk menjadi manusia yang tidak mengutamakan dirinya sendiri, namun selalu memerhatikan rangsangan sosial dan moral. Sedangkan Mulawarman (2013:161) mengungkapkan dalam Pancasila terdapat penyatuan antara sains dan agama serta kesatuan yang nyata antara kepentingan obyektifitas dan subyektivitas, materialitas diri, sosial dan masyarakat sekaligus batiniah spiritualitas diri sosial dan masyarakat yang memiliki nilai Ketuhanan. Alhasil, esensi Pancasila inilah yang kemudian dapat mengangkat nilai kepribadian bangsa Indonesia dalam diri akuntansi yang berdasarkan kearifan dan kepribadian masyarakat Indonesia.

Objek penelitian yang akan diteliti adalah beberapa mahasiswa yang mengikuti acara Konferensi Nasional Akuntansi Pancasila Jilid Pertama, yang kemudian masih terjalin silahturahminya, beberapa kerabat dekat dalam sebuah ikatan organsasi yang bernama Ikatan Mahasiswa Akuntansi Indonesia, dan beberapa kerabat dekat yang berasal dari almamtaer yang sama yakni Politeknik Negeri Malang. Terhitung jumlah keseluruhan informan ialah 20 dengan berbagai perguruan tinggi dan tingkat semester yang berbeda. Pemilihan para informan tersebut di atas dilakukan secara sengaja, berdasarkan kriteria yang dijelaskan oleh Bungin $(2003,54)$, bahwa informan merupakan individu yang telah cukup lama dan intensif menyatu dengan kegiat- an atau medan aktivitas yang menjadi sasaran penelitian. Maka daripada itu, pemilihan informan hanya melalui intuisi pribadi semata yakni dengan melihat seberapa pesat perkembangan pemikiran informan dalam mengkaji ilmu akuntansi itu sendiri dan mengkaji ilmu akuntansi lebih lanjut yang kemudian direlevansikan dengan pemahaman ideologi Pancasila.

Kemudian, dari dua puluh (20) informan yang ada, nantinya hanya akan diambil tiga (3) informan saja untuk kemudian dianalisi lebih mendalam jawaban atas pertanyaan yang telah diberikan. Pemilihan ketiga informan (yang kemudian disebut informan inti) tersebut lebih dikarenakan pengalaman panjang mereka di dalam proses perkuliahan, materi perkuliahan yang sudah ditempuh juga cukup banyak (mulai dari pengantar akuntansi, akuntansi keuangan, etika bisnis dan profesi dll). Informan tersebut secara mendalam memberikan jawaban yang lebih komprehensif dari munculnya suatu fenomena yang terjadi dari pengalaman yang mereka ungkapkan.

Pengumpulan informasi dilakukan secara intensif pada pertengahan bulan Desember 2015 sampai dengan pertengahan bulan Januari 2016 melalui wawancara yang tidak terstruktur, tidak terjadwal, dan dilakukan sedemikian rupa sehingga dalam memberikan informasi, para informan tidak cenderung mengolah atau mempersiapkan informasi tersebut lebih dulu, serta dapat memberikan penjelasan apa adanya.

Tabel 1. Informan Penelitian

\begin{tabular}{llcl}
\hline No. & \multicolumn{1}{c}{ Nama Informan } & Semester & \multicolumn{1}{c}{ Asal Perguruan Tinggi } \\
\hline 1 & M. Dzikri Hadiyaroyyan & VIII & Universitas Indonesia \\
2 & M. Hilmi Kinandana & VIII & Universitas Trisakti \\
3 & Nita Erviana & VIII & Universitas Islam Negeri Yogjakarta \\
4 & Aun Alinda Findi & VI & Universitas Negeri Yogjakarta \\
5 & Pramudya & II & Universitas Negeri Surabaya \\
6 & M. Iqbal Yoga Pratama & VI & Universitas Airlangga \\
7 & Arseno Feri Alzahabi & IV & Politeknik Negeri Malang \\
8 & Fitri Nur Rilah & IV & Universitas Padjajaran Bandung \\
9 & Dwi Sumiyati & II & Universitas Islam Negeri Malang \\
\hline
\end{tabular}




\begin{tabular}{llcl}
\hline 10 & Mirza Ruzbihan Rizfi & VIII & STIEM Bongaya Sulsel \\
11 & Endang Puji Lestari & IV & Universitas Diponegoro \\
12 & Audita Dwi Larasati & VIII & Universitas Brawijaya \\
13 & Anisa Risky Hendrayati & IV & Universitas Hasanuddin \\
14 & Ghylan Al Ghiffary & II & Politeknik Negeri Malang \\
15 & Andi Liani Esa & VIII & Politeknik Negeri Malang \\
16 & M. Andi Nur Kholis & VI & Politeknik Negeri Malang \\
17 & Rizky Febryansyah & VI & Universitas Mulawarman \\
18 & Faiz Zahid Zain & VIII & Universitas Sriwijaya \\
19 & Eko Hidayat & VI & Universitas Islam Negeri Jakarta \\
20 & Nurjanah & VI & Politeknik Negeri Jakarta \\
\hline
\end{tabular}

Catatan:

1) Nama-nama informan adalah bukan yang sebenarnya;

2) semseter dan asal perguruan tinggi adalah data yang sebenarnya/asli; dan

3) yang diberi warna kuning ialah informan inti.

\section{Pembahasan}

\section{Mendeskripsikan Pemahaman Akuntansi Dalam Ranah Pendidikan}

Beberapa hasil penelitian dicontohkan penelitian Mulawarman (2006) menunjukkan bahwa akuntansi adalah ilmu yang sarat nilai, akan tetapi nilai apa yang setiap individu yakini benar dalam memahami akuntansi kembali lagi bagaimana cara mereka menyerap ilmu yang mereka pelajari. Lebih lanjut Mulawarman (2006) menambahkan ketika pendidikan akuntansi yang sarat nilai dan dirasuki oleh akuntansi konvensional yang saat ini masih didominasi kapitalisme barat, maka karakter sistem pendidikan akuntansi menjadi kapitalistik pula. Akuntansi kapitalistik erat kaitannya dengan rasionalitas. Rasionalitas berkaitan erat dengan konsep Utilitarisme (Kamayanti, 2012). Utilitarisme menurut Bertens (2000) dalam Ari Kamayanti (2012), sebagai teori etika cukup dekat dengan cost-benefit analysis yang selalu berpikiran ekonomis, memperhitungkan untung dan rugi atas suatu tindakan, biasanya dipakai dalam konteks bisnis. Manusia adalah mahkluk yang membutuhkan penyelarasan konsep duniawi (EQ dan IQ) dan konsep spiritual (SQ). Adalah pemahaman yang salah bila insan pendidikan menganggap kecerdasan intelektual adalah yang utama, sementara sisi rasa dan batin justru dipinggirkan. Ketika kecerdasan intelektual menjadi hegemoni yang kuat, disadari atau tidak hal ini juga menindas sistem pendidikan dan merasuki juga pada peserta didik (Yudistira, 2013).

Lebih jauh, dapat disebutkan pula bahwa penyadaran dan pembangunan good character dan good attitude pada seorang diri manusia dalam ranah pendidikan pastinya akan selalu dipengaruhi oleh value of knowledge yang diserap manusia yang dalam hal ini ialah mahasiswa, kebijakan institusi maupun guru atau dosen, bahkan bila tergantung pada ilmu yang diberikan, serta sistem sosial-politik-budaya dimana ilmu dikembangkan (Mulawarman dan Ludigdo, 2010). Demikian halnya dalam dunia pendidikan akuntansi, seberapa besar peranan pendidikan akuntansi dalam mengembangkan pengetahuan dan karakter peserta didik. Seringkali pendidikan akuntansi didominasi rasionalitas dan logika ekonomi. Rasionalitas dan logika ekonomi adalah bagaimana akuntansi dapat berperan untuk menunjang pencapaian keuntungan yang maksimal dari entittas bisnis.

Dengan menelaah lebih lanjut kedua paragraph diatas, cukuplah kuat bahwa toeri costbenefit analysis banyak dipakai dalam konteks ekonomi sehingga secara tidak langsung terjadi proses hitung-hitungan layaknya menghitung untung dan rugi dalam konteks bisnis. Ada indikasi bahwa bentuk pemikiran rasional merupakan produk kecerdasan intelektual menjadi kuasa 
yang luar biasa kuat pengaruhnya bagi kehidupan manusia karena merupakan modal satu-satunya untuk membangun pengetahuan. Padahal intelektualbukanlahkecerdasanyangyangmenjadi tolak ukur kesuksesan seseorang. Akhirnya ada suatu pemahaman yang salah jika para insan pendidikan hanya terpaku pada kemanunggalan intelektual. Akibatnya, pemahaman yang dihasilkan pun juga terpaku pada satu sumber saja. Disadari atau tidak kecerdasan intelektual sebetulnya telah melakukan penindasan terhadap sistem pendidikan dan akhirnya juga pada jati diri peserta didik (Triyuwono, 2007) dalam Kamayanti (2012).

Dengan meminjam pendapat Kamayanti (2012) di atas, penulis pun mulai tergerak untuk bertanya kepada tiga orang informan yang telah disebutkan sebelumnya, yakni: 1). M. Dzikri Hadiyaroyyan (Universitas Indonesia); 2). Nita Erviana (Universitas Islam Negeri Yogjakarta; dan 3). Anisa Risky Hendrayanti (Universitas Hasanudin). Menarik untuk dikaji, melalui hasil proses wawancara terdapat beberapa perspektif intelektual yang sangat kuat dari jawaban yang mereka keluarkan. Hal ini mengindikasikan bahwasanya mereka mengharapkan agar akuntansi berdiri di atas pondasi nilai-nilai ideologi bangsa sendiri yang kokoh, dalam hal ini akuntansi yang berlandaskan falsafah Pancasila. Alhasil, menurut penulis, ketiga informan sudah mempunyai jiwa idealisme yang sangat baik.

M. Dzikri Hadiyaroyyan selaku mahasiswa Universitas Indonesia yang saat ini sedang menempuh semester delapan menuturkan kalau pemahamannya terhadap diri "keakuntansian" di Indonesia awalnya ialah Pro Pancasila. Hal ini dapat dianalogikan melalui konsep double entry sebut beliau. "Ketika ada debit pasti ada kredit, bearti ini kan adil? Konsekuensinya, ketika salah satu sisi tidak balance, maka kita akan terus berusaha mencari kesalahannya. Jadi menut saya, akuntansi itu adalah ilmu yang memberikan suatu pelajaran tentang keadilan" ungkap Dzkri. Tidak mengherankan bila bagi Dzikri, akuntansi adalah alat/sarana untuk menyajikan hasil laporan keuangan yang harus sesuai dengan kenyataan yang ada, agar tidak terjadi ketimpangan di salah satu sisi. Beliau juga menambahkan, disinilah peran pendidik untuk membentuk pemahaman tentang bagaimana wujud akuntansi tersebut.

Ada signal positif, yang dapat direkam dari penuturan Dzikri mengenai kesan dan pesannya pertama kali memahami dunia akuntansi. Kata "keadilan" hadir menjadi bumbu manis yang mungkin saja menjadi wujud akuntansi saat ini. Maka daripada itu, penulis pun mencoba untuk mengupas lebih mendalam kata keadilan yang disebutkan Dzikri. Ada hal yang menarik yang menjadi poin penting panggung akuntansi saat ini yakni:

"Di awal saya memang mengatakan bahwa akuntansi adalah ilmu yang menggambarkan nilai-nilai keadilan, namun saya sering kali galau. Jujur saja, hampir 3,5 tahun saya kuliah dengan notabene mahasiswa jurusan akuntansi, baru setelah saya menempuh mata kuliah teori akuntansi saya mulai merasa ada beberapa kejanggalan yang terjadi selama berproses belajar akuntansi. Sebelum-sebelumnya, amanah saya sebagai seorang mahasiswa (dalam hal ini bidang keilmuan akuntansi) yakni agent of change, social control, and iron stock hanya melekat dipundak, tanpa ada kesadaran untuk mengkaji lebih lanjut atau bahkan mengkritisi. Bahkan parahnya dahulu saya tidak mengerti unsur-unsur apa saja yang melekat pada akuntansi (Utilitarian, Kapitalis, Egois, Apatis) dari awal akuntansi lahir hingga berkembang saat ini. Alhamdulilah, sekarang saya mengerti tentang keegoisan akuntansi yang disimbolkan pada pembuatan laporan keuangan yang sering kali direkayasa karena untuk memperoleh suatu kepentingan."

Penulis memahami pernyataan dari Dzikri sebagai usaha Dzikri untuk mencoba memahami suara hatinya sebagai proses kesadaran yang beliau peroleh setelah menempuh mata kuliah Teori Akuntansi. Dzikri juga menambahkan bahwa ada perasaan kecewa yang beliau rasakan karena kesadaran melalui suara hati terganjal oleh sistem kapitalis yang telah mengakar kuat di Indonesia yang disimbolkan melalui perekayaan 
laporan keuangan sebagai proses pencitraan perusahaan melalui konsep laba.

Maka tidak heran jika sistem pendidikan akuntansi saat ini menuntut mahasiswa untuk taat dan patuh terhadap aturan-aturan yang telah diciptakan seperti konsep laba yang berasal dari pendapatan dikurangi beban. Disamping itu, kurangnya keterlibatan mahasiswa untuk mengkaji setiap elemen laporan keuangan sangatlah kurang, hal ini dikarenakan proses pembelajaran pendidikan akuntansi yang lebih berfokus pada pengasahan ketrampilan teknis mahasiswa lewat buku-buku akuntansi yang banyak membahas materi tentang penyusunan laporan keuangan. Padahal ada kemungkinan keterkaitan didalam duniaprofesi, aturan-aturan yang menjadi elemen pembentuk laporan keuangan, tidak selamanya bisa menyelasaikan kasus di lapangan.

Aspek rasionalitas yang begitu mendominasi didalam pendidikan akuntansi mampu ditutupi oleh Dzikri dengan adanya usaha Dzikri untuk membuka diri terutama suara hatinya dalam menanggapi pemahaman akuntansi yang beliau dapatkan di bangku perkuliahan. Akhirnya, Dzikri pun mampu keluar dari konsep akuntansi konvensional yang selalu memandang akuntansi dari perspektif ekonomi. Akuntansi baginya memang sebagai sarana untuk menghasilkan laporan keuangan, termasuk laporan keuangan laba rugi itu sendiri yang wajib ditemukan untuk menggambarkan keadaan suatu perusahaan, namun sepatutnya ditambahkan unsur-unsur keadilan agar dalam proses pembuatannya tidak mengalami ketimpangan sosial. Sungguh sangat disayangkan, suara hati Dizikri yang mengandung ciri masyarakat madani ini harus dikubur akibat sistem pendidikan yang berlaku demikian adanya yang mau tidak mau harus beliau ikuti.

Informan kedua yakni Nita Erviana yang berasal dari Universitas Islam Negeri Yogjakarta menyatakanbahwasudahsaatnya"keakuntansian" di Indonesia untuk keluar dari zona zaman yaitu menuju zona the new accounting yang berlandaskan nilai-nilai transendental sehingga selalu ada proses bagiamana cara manusia untuk bertanggungjawab kepada Tuhannya dan selalu adanya proses rasa syukur yang selalu menghiasi setiap langkah keputusan yang telah diambil.

"Jujur aja aku sekarang lagi suka sama akuntansi syariah, karena sesuai dengan agamaku yaitu Islam. Melalui akuntansi syariah inilah aku kembali memahami bagaimana seharusnya akuntansi itu di gunakan, yah pastilah untuk hal-hal yang menjadi perintah Tuhan bukan laranganNya. Apalagi sebagai seorang muslim, aku berusaha untuk menjauhi dosa, agar aku tidak masuk neraka. Akhirnya melalui akuntansi syariah aku sadar bahwa ada suatu larangan untuk menghindari bunga bank. Aku pernah baca kalau kita masih saja mengejar yang namanya "bunga bank" hal ini dianalogikan seperti orang yang gila hidupnya tidak pernah tenang karena selalu dibayang-bayangi dosa karena bunga bank itu. Naudzubillah, semoga kita dilindungi yah".

Dari pernyataan Nita tentang akuntansi haruslah memiliki unsur-unsur nilai ketuhanan seperti yang telah tertulis di dalam Al-Quran dan Al-Hadist diharapkan membuat setiap langkah manusia khususnya Nita untuk selalu memahami bahwa akan ada proses dimana akan mempertanggungjawabkan semua tindakannya dihadapan Tuhan. Ketertarikan Nita untuk terus mengkaji akuntansi syariah sebaai proses pengamalan dari ajaran agamanya turut membantu Nita memahami apa saja yang yang harus beliau hindarkan karena merupakan bentuk Larangan Tuhan seperti tidak terlalu mengejar yang sifatnya material seperti dicontohkan melalui pernyataan pertama Nita yaitu bunga bank. Bunga bank yang merupakan perwujudan dari Riba adalah sesuatu yang tidak diperobolehkan, namun penting untuk diingat bahwasanya wujud riba tidak hanya berbentuk bunga bank saja, tetapi juga bisa menjelma seperti keinginan seorang pedagang untuk memperoleh laba yang sangat tinggi. Alhasil pedang tersebut pun memiliki sifat tamak/rakus dan parahnya ada kemungkinan seorang pedagang tersebut akan menghalalkan segala cara untuk memperoleh laba tersebut.

Melihat begitu meyakinkannya Nita dalam memberi penjelasan kepada penulis 
tentang pemahamannya terhadap pendidikan akuntansi Indonesia, penulis pun kembali bertanya untuk menggali informasi lebih lanjut tentang bagaimana realisasi atau apa yang telah Nita lakukan sebagai bentuk dari kesadarannya akan nilai-nilai ketuhanan dalam aktivitas seharihari. Nita pun memberikan penjelasannya:

"Jadi setiap malam yah Ray setelah aku pulang kuliah atau selesai menerima mata kuliah, aku selalu berusaha untuk introspeksi diri, kemudian mencatat di buku harianku, tentang positif dan negatif yang sudah aku lakukan terutama melalui pengaplikasian ilmu akuntansiku, apakah lebih banyak mengarah ke positif, atau malah kenegatif. Aku introspeksi diri terhadap apa saja yang sudah aku lakukan pada hari itu. Tujuan aku melakukan semua ini ialah sebagai bentuk usaha seorang hamba untuk kembali dekat dengan Tuhannya. Jadi suatu ketika, aku pernah membaca buku tentang manajemen syariah Ray, terus aku mencoba untuk memahaminya. Bukan isu yang aneh lagi bukan, jika akuntansi kita saat ini bernilai kapitalis, apalgi dengan konsep entity theory yang kita tau adalah simbol dari teori Adam Smith. Aku heran aja sih Ray, kenapa yah akuntansi syariah kita tetap pakai double entry yang jelas-jelas ialah produk dari entity theory itu sendiri. Coba aja cek PSAK 101106, apa aku yah yang salah?"

Kesadaran akan Tuhan yang kemudian direalisasikan dengan cara melibatkan suara hati dan introspeksi diri oleh Nita, mampu menyokong pendapat Nita yang pertama yakni dengan kesadaran Nita untuk lebih memahami perbedaan yang seharusnya melekat pada ruh akuntansi syariah dengan ruh dari akuntansi kapitalis. Namun, Nita dihadapi dengan situasi "kegalauan" yang dapat dilihat dari pernyataan Nita yang mengungkapkan bahwa mengapa jika dilihat dari PSAK 101-106 akuntansi syariah masih menggunakan sistem double entry yang merupakan produk dari entity theory.

Kesadaran berketuhanan oleh Nita direlevansikan dengan pengalaman ibadah sehari-harinya sehingga Nita terkesan agamais. Implikasinya adalah seharusnya memahami akuntansidisertaidengankesadaranakannilai-nilai ketuhanan agar mahasiswa akuntansi mempunyai karakter spiritualis. Nita sangat menyayangkan bahwa sistem yang berlaku di Indonesia menjadi penghambat untuk merealisasikan kesadaran Berketuhanannya tersebut, sehingga dibutuhkan keyakinan yang kuat untuk merubahnya. Ketertarikan Nita terhadap akuntansi syariah tidak dapat ditumbuhkembangkan di bangku perkuliahan, karena Nita belum pernah sama sekali menempuh mata kuliah terkait.Alhasil, melalui pernyataan Nita yang kedua, Nita pun selalu berpandangan bahwa akibat pengaplikasian akuntansi syariah yang masih bersandar pada entity theory adalah bagian dari logosentrisme kapitalis pada akuntansi syariah yang kemudian disebut dengan era kapitalisme syariah.

Berbeda halnya dengan saudari Annisa Risky Hendryati yang mengungkapkan bahwa pemahamannya tentang akuntansi di masa SMA hanyalah sebagai sarana untuk membantu sebuah entitas untuk menyajikan laporan keuangan sebagai proses pertanggungjawaban kepada para stakeholder. Berikut penjelasannya:

Dulu aku mikir akuntansi tuh sempit banget Ray, sekedar sebagai sarana untuk mencatat, menjurnal, terus memposting ke buku besar, bikin neraca saldo, terus identifikasi jurnal penyesuaian, sampai akhirnya terbentuklah laporan keuangan. Namun semenjak kuliah, aku baru sadar kalau akuntansi itu luas banget, karena aku gak hanya menempuh akuntansi dasar, tapi juga juga belajar bagaimana menghitung saham dan obligasi (perwujudan akuntansi menengah), menghitung hpp (perwujudan akuntansi biaya), menggabungkan neraca perusahaan induk dan anaknya (perwujudan akuntansi lanjutan). Jadi akuntansi bagi aku sekarang itu adalah sebagai bentuk proses bertanggung jawab lebih dari sekedar membuat laporan keuangan. Tentunyakita sepakat bukan setelah laporan keuangan dibuat, timbul kegiatan baru yaitu proses mempertanggungjawabkannya 
kepada para pemangku kepentingan bukan?"

Anggapan Annisa bahwa akuntansi ialah sarana untuk membantu sebuah entitas dalam membentuk laporan keuangan tercipta dikarenakan kurangnya kesadaran Annisa di masa SMA untuk lebih mendalami elemenelemen dalam laporan keuangan. Misalnya, Annisa tidak mencoba untuk berusaha lebih peka dalam memberikan alasan mengapa konsep persamaan akuntansi harus "aset sama dengan hutang ditambah modal", atau lebih jauh lagi Annisa belum pernah terpikirkan untuk mencoba melakukan pendefinisian secara pribadi terhadap elemen-elemen dilaporan keuangan misalnya mengenai istilah laba.

"Oh iya Ray, sebagai tambahan ketika aku masuk kuliah tepatnya di semester empat, aku mulai merasa janggal dengan konsep laba. Kok bisa? Alasannya aku melihat potret kehidupan para pebisnis saat ini. Banyak diantara mereka yang tak segansegan melakukan perekayasaan pada laporan keuangan dengan meningkatkan labanya dengan mengurangi nilai beban dari nilai yang seharusnya. Itu kan curang yah Ray, sama kayak kasus Enron, dimana coba etikanya mereka. Terus aku berkaca pada agama islam, bahwa sebenarnya ada konsep zakat yang harus kita dahulukan, yaitu mendistribusikan sebesar 2,5\% dari pendapatan kita kepada pihak-pihak yang berhak menerimanya. Zakat ini juga kan bisa jadi representansi dari nilai-nilai pancasil Ray, bahwa kita harus adil dan tolong menolong antar sesama. Makanya Ray aku baru sadar kalau akuntansi itu adalah ilmu untuk bertanggungjawab bukan sekedar membuat laporan keuangan saja."

Menindaklanjuti pernyataan Annisa yang kedua, penulis pun berkesimpulan bahwa adanya pemahaman terhadap akuntansi yang sangat kontras ketika Annisa semasa di SMA dengan Annisa semasa di perkuliahan. Saat ini Annisa berani beranggapan bahwa banyak di antara pebisnis melakukan tindakan yang sangat tidak etis seperti melakukan kegiatan memark up laba sehingga bisa jadi penyajian terhadap nilai-nilai di laporan keuangan pun menjadi tidak relaibilitas dan tidak memiliki unsur validitas. Kita sepakat bahwa kegiatan memark up laba ialah perbuatan yang keji sebagai representasi dari sifat rakus dan tamak dari keegositikan manusia. Keegoisan ini juga mungkin akan membawa manusia menuju arus yang mengandung unsur-unsur yang dapat melupakan kehidupan setelah "duniawi" seperti secara sengaja tidak membayar zakat yang mana merupaka suatu kewajiban yang harus dilakukan oleh kaum muslimin misalnya.

Annisa lebih lanjut menjelaskan bahwasanya proses pertanggungjawaban kepada para stakeholders harus memperhatikan dua sub sub fokus yakni manusia itu sendiri dan yang kedua ialah environmental impact. Sub fokus yang pertama yaitu manusia dimana Annisa ingin adanya konsep "memanusiakan manusia" melalui keeksistensian dari sebuah nilai kehumanisan. Artinya, seorang pebisnis atau sebuah entitas dikatakan telah bertanggungjawab ketika telah adanya unsur kehumanisan, misalnya adanya bantuan dana corporate social responsibility (CSR) yang menggalakkan dana untuk korban musibah banjir disuatu daerah, pemberian beasiswa, pembagian dalam bentuk natura, dll. Selanjutnya, proses tanggungjawab juga tidak melupakan yang namanya lingkungan. Parameter keberhasilan pertanggungjawaban pada sub focus kedua ini menurut Annisa dapat diilhami seperti adanya penanggulangan resiko pencemaran lingkungan.

Melalui penjelasan diatas inilah hal yang ditonjolkan oleh informan ketiga ialah adanya harapan terhadap keeksistensian akuntansi dalam perwujudan nilai humanis dan nilai kepedulian terhadap lingkungan. Konsekuensi yang hendak dicapai akhirnya berujung pada ada atau tidaknya kesadaran para pebisnis atau suatu entitas untuk memahami bahwa akuntansi tidak hanya sekedar sebagai sarana untuk membuat laporan keuangan saja, namun juga dapat dijadikan sebagai sarana untuk bertanggungjawab kepada manusia itu sendiri dan kepada alam. Nita sangat kecewa bahwa sistem akuntansi yang berlaku di Indonesia tidak berjalan sesuai dengan harapannya yang ingin menciptakan suasana yang 
damai, adil, dan harmonis.Keidealisan Annisa dalam memandang ilmu akuntansi pun sangat penting untuk diapresiasi mengingat Annisa telah berhasil mengamalkan ideologi bangsanya yaitu Pancasila untuk menuju konsep akuntansi yang lebih humanis.

\section{Pengungkapan Konsep Diri "Keakuntasian" di Indonesia: Dalam Panggung Politik Kapitalis atau Pancasila?}

Dari karya Bailey (1998), Watts dan Zimmerman (1986), dalam Triyuwono (2012) dapat disimpulkan bahwasanya faktor sistem politik (ideologi) dan ekonomi adalah faktorfaktor penentu yang mempunyai andil besar dalam memberikan kontribusi warna dan bentuk akuntansi. Dapat penulis contohkan seperti misalnya ketika penguasa suatu negara lebih memilih untuk menerapkan sistem ekonomi sosialis, maka pilihan untuk menggunakan sistem ekonomi sosialis pun tidak akan dapat diperbaharui, yang kemudian baru akan mempengaruhi sistem akuntansi itu sendiri.

Hadiwinata (1994), dalam Triyuwono (2012) mengindikasikan ternyata sebelumnya Hadiwinata telah berhasil menyajikan metafora yang apik tentang kuasa dan pengetahuan sistem ekonomi kapitalis sebagai produk modernisme. Untuk menggambarkan hal ini, ia menggunakan metafora 'theatrum politicum' (panggung politik, yaitu pertemuan antara bermacam-macam karakter dalam berbagai wacana yang telah diatur sedemikian rupa (Hadiwinata, 1994). Bagi Hadiwinata, kapitalisme dalam kenyataannya tidak beda dengan 'panggung politik'.

Karena saat ini yang sedang menjadi logosentrisme adalah ideologi kapitalisme, maka adalah suatu hal yang logis atau wajar jikalau akuntansi kapitalis juga akhirnya menjadi logosentrisme (Triyuwono, 2012). Ditambah lagi, dikarenakan realitas sosial telah terbentuk melalui nilai-nilai kapitalisme maka mau tidak mau sistem akuntansi di Indonesia pun akan terbawa arus kapitalisme seperti pernyataan sebelumnya. Alhasil, hegemoni kapitalisme pun akhirnya lambat laun akan mencoba untuk merangsang pola pikir masyarakat kita dengan kuasa yang sangat kuat, sehingga akan adanya pengetahuan dan aksi para akuntan kita, tenaga pendidik akuntansi kita, dan mahasiswa akuntansi kita akan menyokong warna kapitalisme dalam dunia akuntansi di Indonesia.

Kapitalisme sendiri dalam akuntansi, menurut Rahmat (2010) merupakan:

"sebuah ideology mainstream yang mengendalikan hampir semua line kehidupan manusia modern. Ia telah mampu mengubah pola perilaku manusia dari pola pikir alturistik menuju pola perilaku yang individualistik. Tidak terkecuali dengan ilmu akuntansi, hegemoni kapitalisme yang kuat dan berakar dalam kapisitasnya sebagai 'induk buaya' dari akuntansi modern. Dengan kata lain kapitalisme lah yang secara aktif ikut berperan dalam memformat bentuk, wujud, dan rupa dari ilmu akuntansi modern."

Salampessy (2011) menyebutkan akuntansi keuangan yang kita praktikkan sekarang ini adalah bagian dari akuntansi modern yang merupakan produk masyarakat barat sejak abad ke-16 sampai abad ke-21 yang sampai saat ini berpanggung politik liberalisme dan kapitalisme, sehingga akuntansi keuangan pun bercorak liberalisme dan kapitalisme. Hal ini dapat dibuktikan pada skala mikro, kita akan melihat bahwa akuntansi modern merupakan anak dari sistem ekonomi kapitalistik (Triyuwono, 2012) yang kemudian dapat kita telaah melalui laporan keuangan neraca dengan label 'laba yang ditahan' yang merupakan bagian dari ekuitas, atau dilaporkan secara khusus dalam laporan laba yang ditahan. Atau kemudian dapat kita lihat pada bentuk ekuitas itu sendiri melalui komponenkomponennya seperti modal saham (biasa atau preferen), agio/disagio saham, laba yang ditahan, dan lain-lainnya. Semakin besar komposisi ekuitas ini terhadap jumlah utang, maka akan semakin akan investasi yang ditanamkan oleh investor pada suatu perusahaan. Ini merupakan ilustrasi sederhana dari dua ciri utama akuntansi kapitalis yang sangat menonjol.

Lalu pertanyaannya: "Kapan Indonesia akan Mengalihkan Pandangan Sistem Akuntansi- 
nya dari panggung politik kapitalis menuju panggung politik pancasila?" Hal ini hanya akan dapat terwujud jikalau Indonesia mampu menunggalkan ideology pancasila nya untuk segala hal. Maksudnya, setiap apapun langkah yang akan diambil harus disadari dengan nilainilai pancasila. Ketika aksi "berpancasila" yang telah diwacanakan terealisasi maka logosentrisme jati diri Indonesia pun sejatinya akan berlogo pancasila. Hal inilah nantinya yang akan dapat mendorong para akuntan, tenaga pendidik akuntansi, paramahasiswadibidangakuntansi,dan seluruh orang-orang yang notabenenya di bidang akuntasi untuk kembali ke proses pemaknaan pancasila.Hasilakhirnya, logosentrisme akuntansi modern bernilai kapitalisme mula kita reduksi secara perlahan seiring dengan ditanamkannya nilai-nilai pancasila, sehingga logosentrisme akuntansi modern bernilai pancasila lahir dengan tersendirinya.

\section{Pemaknaan Konsep Diri "Keakuntansian" Menggunakan Suara Hati Sebagai Wujud Kesadaran Oleh Informan: Dalam Panggung Politik Kapitalis atau Pancasila?}

Melalui mata kuliah teori akuntansi, penulis berhasil mendeteksi setidaknya ada 3 poin penting bagaimana sistem akuntansi kapitalis itu dibangun. Pertama akuntansi modern, dibiarkan dan diilhami sebagai akuntansi yang sarat dengan nilai-nilai kapitalisme. Kapitalisme itu sendiri berdasar pada konsep etika utilitarianisme. Etika utilitarianisme adalah konsep nilai di mana nilai baik-buruk, benar-salah didasarkan pada konsekuensi sebuah perbuatan yang diukur dengan utilitas (utility). Artinya, jika sebuah perbuatan menghasilkan utilitas, maka perbuatan tadi dikatakan etis. Tapi sebaliknya jika perbuatan tadi menghasilkan disutilitas (disutility), maka perbuatan tadi adalah perbuatan yang tidak etis.

Kedua, akuntansi modern sangat identik dengan angka-angka. Triyuwono (2012) menambahkan bahwa angka-angka tersebut adalah pusat perhatian dan ini adalah salah satu bentuk logosentrisme dari akuntansi modern. Terakhir adalah konsep realitas yang terlalu berlebihan. Realitas yang diciptakan oleh akuntansi modern adalah realitas yang tidak ideal. Yang diinginkan adalah realitas yang sarat dengan nilai-nilai etika (etika dalam pengertian menyeluruh) yaitu, realitas yang di dalamnya terdapat jaring-jaring kuasa Ilahi yang akan mempengaruhi atau "memperangkap" pengguna informasi akuntansi untuk selalu bertindak etis, baik kepada sesama manusia, kepada lingkungan alam, maupun pada Tuhan sendiri (Triyuwono, 2012). Untuk keperluan ini, maka dibutuhkan bentuk akuntansi yang memang kondusif untuk keperluan tersebut. Bentuk akuntansi yang ditawarkan untuk keperluan tersebut adalah akuntansi syari'ah yang mampu memberikan informasi yang lebih adil bila dibandingkan dengan akuntansi modern. Karena dalam proses konstruksinya, akuntansi syari'ah berdasarkan pada asumsi hakikat diri manusia yang sejati dan pemahaman aspek ontologi yang lebih lengkap bila dibanding dengan akuntansi modern.

Menjadi pertanyaan yang sangat dilematis jika kita dihadapkan pada pertanyaan dimanakah letak keeksistensian pemaknaan konsep "keakuntansian", apakah dalam panggung kapitalis atau panggung Pancasila? Mengacu pada apa yang telah diungkapkan oleh Tricker (1978) bahwa akuntansi adalah anak dari dari budaya masyarakat dimana akuntansi dipraktekkan, hal ini pun memberi pemahaman baru bahwa nilai masyarakat memiliki peranan yang penting dalam mempengaruhi bentuk akuntansi. Hal ini pun sama pengertiannya seperti pernyataan Suwardjono (2008) bahwa akuntansi yang dipraktekan dalam suatu wilayah negara sebenarnya tidak terjadi begitu saja secara alamiah, akan tetapi sengaja dirancang dan dikembangkan untuk mencapai tujuan tertentu. Maka daripada itu, tidak heran jika bila struktur dan praktik akuntansi akan berbeda antara negara yang satu dengan negara yang lainnya.

Lalu bagaimana dengan konsep "keakuntasian" milik Indonesia, apakah telah sesuai dengan ideologi bangsa yakni Pancasila atau malah sesuai dengan ideologi kapitalis? Menarik untuk dicermati, mengingat adanya proses pengadopsian sistem akuntansi dari negara barat yakni IFRS, memungkin sistem akuntansi di Indonesia 
akan bertolak belakang dengan ciri kepribadian bangsa, seperti negara yang barat terkenal dengan logosentrisme kapitalis atau liberalisnya yang bernilai egoistik dan materialistik, sedangkan Indonesia terkenal dengan logo sentrisme Pancasila yang mengandung nilai-nilai spritual dan kehumanisan. Hipotesis awal pun dapat dikatakan bahwa mungkin saja akan tereduksinya nilai leluhur yang menjadi kepribadian bangsa Indonesia. Beranjak dari hal ini, penulis pun mecoba untuk menggali informasi melalui dua puluh informan yang tersebar di masing-masing perguruan tinggi.

Untuk menggali informasi yang lebih mendalam, penulis memfokuskan wawancara dengan informan yang sama dengan sebelumnya yakni Dzikri, Nita, dan Annisa mengenai pemahaman mereka tentang masalah tersebut. Ketika penulis mencoba untuk berdiskusi kepada Dzikri, di posisi manakah sistem "keakuntansian" Indonesia, apakah kapitalis atau Pancasila, Dzikri menjawab:

"Jika dilihat dari kulitnya, sifat akuntansi itu mengarah ke Pancasila kok. Buktinya adanya proses pencatatan untuk melihat keseimbangan antar dua sisi (kredit atau debit) adalah pengaplikasian dari bentuk sila kelima. Kemudian adanya istilah pertanggungjawaban kepada stakeholder, dan adanya annual report sebagai bentuk transparansi, juga hasil perwujudan dari butirbutir Pancasila. Tapi ini anggapan saya ketika masih disemester 1-5 loh. Hehe.."

Melalui dialog singkat tentang gambaran awal Dzikri mengenai panggung "keakuntansian" di Indonesia, penulis dapat mengambil esensi dari pengalaman atau kesadaran Dzikri akuntansi adalah ilmu yang merupakan turunan dari pengaplikasian Pancasila. Menurut Dzikri, Pancasila juga mampu membentuk good charac-ter seseorang yang dibingkai melalui adanya proses penyajian laporan yang transparansi, adanya proses bertanggungjawab, dan paling penting ialah sebagai tindakan dalam pengamalan Pancasila. Memang sudah seharusnya, masyarakat yang berkecimpungan dalam dunia akuntansi khususnya akuntan berlaku transparan, sesuai dengan keadaan yang sebenarnya tidak ada rekayasa dalam laporan keuangan dengan tujuan apapun didalamnya. Nilai keterbukaan harus menjadi nilai yang selalu dihidupi oleh akuntan dalam melakukan pekerjaan sehingga mampu menghasilkan laporan keuangan yang humanis.

Meskipun demikian, Dzikri tidak mempungkiri apabila akuntansi modern yang berjalan saat ini memang hanya fokuspada nilainilai maskulin yang merupakan perwujudan dari Dewa Yang. Kesadaran ini diungkapkan Dzikri sebagai berikut:

“Tapi Ray, kamu sadar gak, sebenarnya kenapa yah Indonesia pakai sistem akuntansi barat? Apa gak malu yah ama negara luar. Negara yang dulu kuat, sama kuatnya dengan Amerika, eh malah mencontek sistem ekonomi orang. Parahnya lagi, yang dicontek itu sistem yang sudah pasti berbanding terbalik dengan ideologi kita. Wajar aja sih sekarang kalau kebanyakan akuntansi konvensional itu tidak punya nilai, jadi tidak ada nilai-nilai yang melandasinya, kita cuma mengukur, menyajikan, kemudian yo sudah....selesai begitu saja. Kemudian sadisnya lagi ialah penyajian laporan keuangan itu Ray, marak sekali kebohongan. Padahal kebohongan itu Cuma buat pencitraan aja, biar para investor banyak yang menanamkan modalnya."

Melalui pernyataan diatas, secara tersirat ada pandangan yang berbeda dengan cara berpikir Dzikri melihat orbit akuntansi di Indonesia. Semula beliau berpikir akuntansi adalah turunan dari Pancasila, kini beliau merevisinya dan kemudian menggantikannya dengan mengatakan bahwa akuntansi Indonesia merupakan turunan dari nilai kapitalisme. Pernyataan Dzikri ini sontak mengingatkan penulis pada pernyataan James (2008) dan Kamayanti (2011) bahwa memang benar adanya kecenderungan sistem akuntansi Indonesia memiliki bias gender maskulin (mendominasi), yang kemudian sebaliknya meninggalkan nilai-nilai feminin (spiritual). Bias gender maskulini tergambar dari corak akuntansi modern yang berorientasi keuntungan maksimal 
bagi invenstor terlepas dari bagaimana caranya memperoleh keuntungan tersebut yang senada dengan pemikiran Dzikri.

Bagi Informan kedua yakni Nita Erviana yang merupakan sosok seseorang yang agamis, akuntansi modern yang diberlakukan di Indonesia terkesan egois yang merupakan representasi dari logosentrisme akuntansi kapitalis. Hal ini dituturkan Nita dengan menggambarkan bagaimana sadisnya perusahaan yang melakukan pemutusan hubungan kerja secara besar-besaran.

"Aduh Ray, jangan berbica humanis deh kalau masih pakai acuan sistem akuntansi yang sekarang. Buktinya toh, sekarang ini banyak perusahaan yang berlomba-lomba meningkatkan labanya dengan mengecilkan beban di neraca. Yah salah satu dampaknya ialah pengecilan nilai beban gaji, jadi gak heran kalau sekarang itu banyak pemutusan hubungan kerja. Terus yang paling ngeselin itu, banyak perusahaan yang angkuh ketika udah melakukan tindakan CSR, terus disiarin dimana-mana. Padahal dampak negatif yang dihasilkan dari kegiatan operasinya itu loh ga sesuai dengan dana CSR yang udah mereka keluarin."

Rasa penyesalan informan kedua atas sikap sebuah entitas dalam hal ini perusahaan sangatlah tinggi. Hal ini mengindikasikan bahwa sosok seorang Nita sangat anti pada perusahaan yang tidak bertanggung jawab atas kegiatan operasional yang mungkin saja memberikan dampak negatif pada lingkungan.

"Kamu tentu ingat bukan bahwa, kebersihan adalah sebagian dari iman. Semboyan itu mengajarkan kita untuk terus menjaga kebersihan, kalau ga berih yah bearti ga beriman. Sesimple itu kok. Lagian kan tuhan juga mengajarkan cara berperilaku yang baik di dalam kehidupan. Terlepas itu mungkin saja adalah hal yang sulit bagi sebagian orang, tapi apakah mau hidup kita dibayangi dengan sampah, bau tidak sedap? Makanya besar harapan aku, perusahaanperusahaan itu bener-bener mengaplikasikan green accounting dan carbon accounting, biar mereka lebih peka lagi terhadap lingkungan. Alhasil negara kita ini enak untuk didatangi, ditambah lagi adanya keramahan yang merupakan wujud dari kepribadian bangsa kita yang peduli akan sesama manusia maupun lingkungannya."

Rasa kekecawaan yang dibalut dengan rasa penyesalan dalam diri Nita, akhirnya memberikan pandangan baru bahwa sebaiknya akuntansi juga harus dibangun melalui rasa kepakaan untuk saling memiliki, mengawasi, mengasihi, dan saling peduli yang merupakan penginternalisasian dari pancasila agar nilai-nilai kehumanisan menjadi potret negara Indonesia. Misalnya kepekaan dalam saling peduli pada lingkungan, dapat dibangun melalui paradigma green accounting dan carbon accounting. Hasil yang diharapkan pun akan tiba seperti hadirnya akuntansi yang merupakan buah pemikiran dari beberapa orang yang diperoleh dari hasil pengamatan serta penelitian mendalam dan akan terus berkembang sejalan dengan permasalahan objektif di dunia nyata misalnya saja green accounting dan carbon accounting seperti yang telah disebutkan Nita. Displin ilmu akuntansi inilah nantinya diyakini akan menjadi bagian dari buah pemecahan masalah dalam menanggulangi kerusakan lingkungan bisa saja terjadi dalam aktivitas lingkungan, berkaitan terutamanya dalam usaha manajemen lingkungan.

Nita kembali berusaha menyadarkan kita akan pentingnya keterlibatan sudut pandang agama demi kehidupan yang lebih baik seperti semboyan "kebersihan adalah sebagian dari iman". Apalagi sebagai seorang muslim, agama memberikan pesan kepada kita untuk terus menjaga kesucian diri, sederhananya adalah menjaga "wudhu". Karena pentingnya keterlibatan agama di segala kehidupan, termasuk dalam keilmuan akuntansi, keterlibatannya tidak bisa disingkirkan begitu saja. Dalam hal ini peneliti cukup kagum dengan pemahaman Nita yang menjelaskan konsep panggung "keakuntansian" di Indonesia menggunakan perpektif spiritualnya.

Ketika mencoba untuk berdiskusi dengan 
Annisa yang merupakan sosok yang perempuan yang tegas, mengenai letak atau posisi sistem "keakuntansian" di Indonesia, dengan tegas dan penuh keyakinan beliau menjawab akuntansi saat ini sarat akan nilai hedoniseme, keserakahan, kerakusan yang merupakan ciri dari akuntansi kapitalis:

"Menurutku, akuntansi yang pas itu bukan akuntansi yang sekarang. Karena kamu sendiri juga tau, kalau aku adalah orang selalu mencoba untuk berpikiran bahwa sesuatu ialah salah, kemudian aku telusuri lebih lanjut. Namun, ketika ditelusuri ternyata benar, barulah aku berkata benar. Aku emang orangnya tidak terlalu cepat percaya. Jadi secara tegas aku katakan, bahwa akuntansi sekarang ini memiliki nilai hedonism, keserakahan, kerakusan. Seharusnya akuntansi itu pakek nilai-nilai Pancasila, biar kita bisa belajar dari pejuangpejuang terdahulu bagaimana berjuang untuk negara. Sekarang ini, konsep memanusiakan manusia aja susah, apalagi mau berkontribusi dan berdidikasi tinggi seperti pejuang terdahulu."

Annisa yang sudah penulis kenal sejak semester satu lewat organisasi yang bernama Ikatan Mahasiswa Akuntansi Indonesia ini adalah pribadi yang sangat idealis disamping punya ketegasan yang tinggi untuk ukuran perempuan. Tak heran jika sedang membahas mengenai keidealisan, pendapatnya selalu menarik. Kemudian Annisa menjelaskan pernyataannya terkait akuntansi yang memanusiakan manusia:

"Aku bermimpi Indonesia memiliki akuntansi yang benar-benar memanusiakan manusia. Karena aku gak suka akuntansi sekarang ini, selalu banyak terjadi pertikaian karena selalu saling memandang yang lain lemah, bahkan memandang manusia hanya sebagai sebuah asset layaknya binatang ekonomi bukan? Di mana harkat martabat manusia coba?"

Adapun Eidetic Reduction yang dapat disampaikan kali ini ialah kita sebenarnya telah mengenal istilah hubungan horizontal dan hubungan vertical. Istilah hubungan vertical adalah hubungan manusia dengan Tuhannya atau dengan kata lain spiritualitas, sedangkan hubungan horizontal adalah hubungan manusia dengan sesama manusia. Ditambah lagi, agama mengajarkan agar kita selalu memiliki hubungan yang baik antar sesama manusia mengingat semua manusia pada hakikatnya mempunyai derajat yang sama di mata Allah. Implikasinya dengan pemahaman akuntansi Annisa adalah, seharusnya manusia sebagai pelaku dalam akuntansi tidak dianggap sebagai aset yang dapat diukur secara kuantitatif, tetapi manusia lebih dari itu. Realisasinya, menurut Annisa dilakukan dengan cara membangun komunikasi yang baik dengan partner kerja, dan mempertimbangkan kesejahteraan karyawan sehingga mereka lebih nyaman dalam bekerja.

\section{Kerja Keras Kapitalis Dalam Membangun Pondasi Sistem Akuntansi Madani Melalui Pengkonotasian Stakeholders}

Dilihat dari dimensi sosial keeksistensian perusahaan memang diperlukan untuk melayani kebutuhan masyarakat. Sepanjang masyarakat masihmemerlukanprodukperusahaan, perusahaan akan tetap dapat eksis. Kegiatan bisnis dalam pandangan barat tidak pernah dikaitkan dengan agama (Agoes, 2011). Padahal kalau ditelusuri dalam ajaran agama-agama besar, ada ketentuan yang sangat jelas tentang kegiatan bisnis ini. Dalam agama islam misalnya, dijumpai suatu ajaran bahwa menjalankan kegiatan bisnis itu merupakan bagian dari ibadah, asalkan kegiatan bisnis (ekonomi) diatur berdasarkan wahyu yang tercantum dalam Al-Qur-an dan Sunnah Rasul (Rahardjo,1990). Selanjutnya Dawam Rahardjo mengatakan bahwa ada tiga doktrin dalam Islam, yaitu: ibadah, akhirat, dan amal saleh Interpretasi yang lebih luas tentang ketiga doktrin ini sudah lama dikaji dan dipahami. Ibadah tidak hanya diartikan dalam arti sempit - hanya menyangkut aspek ritual seperti sholat dan puasa-tetapi juga terkait urusan mencari rejezi dan menuntut ilmu. Dalam doktrin akhirat, kegiatan manusia tidak semata-mata hanya memburu surga dengan mengabaikan atau menjauhi kewajiban-kewajiban 
hidup didunia. Begitu pula interprestasi luas mengenai amal saleh tidak hanya dalam bentu charity, seperti sumbangan untuk membangun mesjid, tetapi juga termasuk kegiatan jual-beli dan sewa menyewa (Rahardjo,1990).

Dewasa ini pun kegiatan bisnis mulai menunjukkan kereligiusannya. Lebih pentingnya lagi adalah munculnya pandangan baru dalam mengelola suatu perusahaan. Pandangan baru ini lebih menyoroti perilaku para eksekutif puncak perusahaan karena perilaku para eksekutif puncak ini sangat menentukan keberlangsungan hidup satu perusahaan. Para eksekutif puncak dituntut untuk tidak hanya bersifat etis, tetapi diharapkan mempunyai tingkat kesadaran transendental atau tingkat kesadaran spiritual.

Para eksekutif yang telah mencapai tingkat kesadaran spiritual ini akan memaknai kegiatan pengelolaan perusahaan sebagai bagian dari ibadah kepada Tuhan yang Maha Kuasa, menjadikan perusahaan yang dikelolanya sebagai sarana untuk melakukan pelayanan secara tulus untuk memajukan kesejahteraan semua pemangku kepentingan, sekaligus menjaga dan memelihara kelestarian alam. Perusahaan yang dikelolanya akan menjadi perusahaan yang tercerahkan (enlightened company).

Perubahan pola pikir pada para eksekutif puncak ini pun disambut penulis dengan penuh kegembiraan, mengingat semenjak menempuh mata kuliah Teori Akuntansi selalu bermimpi Indonesia untuk keluar dari zona kapitalis. Makadaripada itu, penulis kemudia mencoba untuk berbincang-bincang kepada ketiga informan sebelumnya untuk melihat pandangan mereka dalam memaknai kata stakeholder.

Pemahaman awal dari makna kata stakeholders bagi Dzikri, Nita, dan Annisa ialah mengacu kepada seseorang ataupun sekelompok orang yang mempunyai hubungan dan kepentingan bagi suatu perusahaan. Kesamaan pemahaman ini terjadi dikarenakan adanya kesamaan penjelasan yang mereka dapatkan dari buku bacaan, tenaga pendidik, majalah, internet, dll sewaktu mereka menempuh pendidikan di perguruan tinggi. Ketiganya juga sepakat bahwa pemangku kepentingan nantinya terdiri atas dua macam yakni kelompok primer dan kelompok sekunder. Kelompok primer ialah kelompok stakeholders yang berinteraksi secara langsung dengan perusahaan, sedangkan sekunder adalah kebalikan dari pendefinisan kelompok primer.

Namun, ketika penulis mencoba untuk mengarahkan ketiga informan untuk mendekonstruksi ulang makna dari kata stakeholder yang sifatnya keluar dari pernyataan sebelumnya, muncul beberapa jawaban yang menurut penulis sangat menarik untuk dikaji secara lebih mendalam. Dalam hal ini Dzikri menambahkan unsur tingkat kesadarannya yang dibungkus dengan teori etika yang beliau peroleh ketika menempuh mata kuliah etika bisnis:

"Berbicara mengenai konsep stakeholder melalui paradigma secara pribadi, saya lebih sepakat mengatakan bahwa konsep stakeholder harus bisa keluar dari pemaknaan kesadaran hewani. Mengapa aku bilang kesadaran hewani? Aku berpikir bahwa konsep pemangku kepentingan saat ini itu hanya berlandaskan teori egoisme dan teori hak aja. Hasilnya pun terkesan negatif, dan kurang enak untuk dipandang. Bersandarnya paradigma kepemilikan dan paradigma pemegang saham, menambah situasi kemirisan yang saya rasakan. Kini makna dari kata tanggungjawab kepada pemangku kepentingan akan diperoleh ketika sasaran perusahaan ialah memperoleh kekayaan dan keuntungan seoptimal mungkin bagi pemegang saham. Nah, jadi seharusnya stakeholder itu ada unsur masyarakat, pemerintah, karyawan, pemasok, itu semua luntur dan hanya difokuskan pada sasaran pemegang saham saja."

Pesan yang hendak ingin disampaikan Dzikri melalui pemaknaan ulang kata stakeholder sebenarnya ialah adanya kelunturan nilai masyarakat, pemerintah, karyawan, pemasok, dll yang juga merupakan bagian dari organ tubuh kata "stakeholder" sendiri. Kelunturan nilai ini kemudian disisipkan dengan tambahan amunisi "pemegang saham", jika porsi dari kata pemegang saham pada stakeholder pun 
menjadi mendominasi. Dalam hal ini, muncul kekhawatiran dari diri pribadi Dzikri yakni perusahaan akan terus menerus mengejar laba guna memberikan kesejahteraan hanya kepada pemegang sahamnya saja.

Pemahaman Dzikri terhadap kata "stakeholder" ialah bahwa adanya pergesaran makna kata stakeholder kearah yang lebih negative karena hanya mementingkan satu kepentingan saja yakni kepentingan pemegang saham. Dalam hal ini, Dzikri mengatakan bahwa tingkat kesadaran yang ditunjukkan ialah kesadaran hewani. Hal ini dapat dibuktikan melalui adanya keegoisan sebuah entitas untuk menggunakan paradigma kepemilikan dan paradigma pemegang saham guna mewujudkan sasaran perusahaan. Akhirnya pun, perusahaan menjadi terperangkap, terkurung, dan terpenjara oleh bayangan sebuah tindakan yang etis jika pelaksanaannya telah menerapkan teori egoisme yang dimana adanya motivasi dari dalam pribadi untuk memunculkan keuntungan pribadi atau suatu kelompok tertentu saja.

Ada jawaban yang menarik tentang pemaknaan ulang kata "stakeholder" menurut Nita. Dengan sosok agamaisnya beliau mampu menghadirkan nilai-nilai transcendental ditengahtengah maraknya nilai keegoisan pada kata "stakeholder" seperti yang telah dikatakan oleh Dzikri tadi.

"Kalau aku sih sederhana mengartikan kata stakeholder itu Ray. Bagi aku stakeholder itulah sarana proses pertanggungjawaban suatu entittas kepada suatu makhluk dan Tuhannya atas kegiatan operasi yang mungkin saja memberikan dampak negative bagi proses kelangsungan kehidupan. Alhasil antara pengelola dan pemangku kepentingan pun sadar bahwa kegiatan bisnis adalah bagian dari ibadah. Kemudian, tujuan bisnis hanya semata-mata untuk memajukan kesejahteraan semua pemangku kepentingan termasuk Tuhan didalamnya. Dan yang paling penting ialah, dalam menjalankan aktivitas bisnis itu jangan lupa untuk terus mampu menjamin kelestarian lingkungan Ray."
Sosok agamis yang dimiliki Nita pun mampu membawa beliau untuk selalu menghadirkannilai-nilaikesadaran transcendental yang berwujud kasih dan sayang. Sasaran perusahaan yang dulunya adalah mengejar laba dapat tergeser dengan paradigma perusahaan yang tercurahkan rahmat dan kasih sayang Tuhan sehingga sasaran perusahaan pun ialah hanya semata-mata mencari rezeki, mencari ridhaNya, dan merupakan bagian dari Ibadah kepada Tuhan melalui pengabdian yang tulus untuk kemakmuran bersama yang diimbangi dengan kelestarian alam.

Selanjutnya pemaknaan ulang kata "stakeholder dari informan ketiga yakni Annisa. Melalui kacamatanya, pendekonstruksian ulang kata "stakeholder" sebaiknya dilakukan proses penginternalisasian butir-butir Pancasila. Menurut pandangan beliau, butir-butir Pancasila menyajikan semua komponen yang bersifat altruistik, mengutamakan kepentingan publik, tidak bersifat materi tetapi malah spiritual, dan pengukurannya pun tidak terlalu saintifik.

"Karena aku pro sama akuntansi Pancasila, maka aku menghendaki pemaknaan ulang kata stakeholder lebih kearah butir-butir Pancasila Ray. Kita masukin deh unsurnya satu persatu. Misalnya pada bagian sila pertama, 'Ketuhanan Yang Maha Esa' melalui konsep ini kata stakeholder haruslah memiliki unsur ketuhanan. Kemudian sila kedua, pemaknaan kata stakeholder harus berwujud sikap manusia yang beradab yakni kembali lagi ke konsep yang aku bilang diawal yaitu memanusiakan manusia. Kemudian lagi misalnya sila kelima, 'Keadialan Sosial Bagi Seluruh Rakyat Indonesia' melalui sila ini, adanya pemaknaan kata stakeholder yang tidak berat sebelah, tidak mengandung unsur-unusr kepentingan suatu kelompok, dan terakhir nantinya adanya pendistribusian secara berkeadilan."

Melalui persepektif Pancasila yang kemudian dimasukkan kedalam kata "stakeholder" dapat dipastikan akan hadirnya nilai-nilai feminim seperti altruistik yang akan menutupi sifat 
egoistik, adanya nilai spiritual yang akan menutup nilai materialistik, adanya nilai publik yang akan menutup nilai private yang merupakan represntasi dari nilai-nilai maskulin. Kehadiran nilai feminim ini menggambarkan adanya kesadaran manusiawi didalam diri Annisa. Tidak heran jika landasan pemaknaan kata "stakeholder" menurut Annisa akan mengutamakan azas kemanfaatan, keadilan, kewajiban, dan keuatamaan. Sasaran perusahaan yang ingin dicapai lebih kearah sosialis yakni untuk mensejahterakan seluruh lapisan masyarakat.

Kesimpulan (Eidetic Reduction) yang bisa peneliti ambil dari pemaparan diatas sebenarnya ialah Annisa mencoba untuk memberikan pelajaran kepada kita bahwa sudah saatnya pemakaan setiap elemen akuntansi itu dalam hal ini "stakeholder" beralih dari saintifik menuju intuitif, dari matematikal menuju artifik, dari maskulin menuju feminism, dan dari material menuju spiritual dengan berpijak pada butir-butir Pancasila. Kecintaan Annisa terhadap Pancasila juga mampu menambah warna dari semangat Annisa untuk menghadirkan nilai-nilai energy positif yang sejalan dengan kebutuhan negara Indonesia.

\section{Mengaksikan Wacana Stakeholder Akuntansi Berbasis Pancasila}

Menelaah pernyataan Ludigdo dan Kamayanti (2012) tentang meyakini bahwa Pancasila bukan hanya dijadikan dasar etika akuntan saja, tetapi Pancasila harus menjadi dasar rekonstruksi dan bahkan dekonstruksi ilmu dan praktik akuntansi di Perguruan Tinggi, maka munculah peran penting Pancasila, selain sebagai nilai moral pembentukan karakter akuntan, namun juga sekaligus penilaian kritis atas konsep, teori dan praktik Akuntansi di Perguruan Tinggi. Mulawarman (2013) juga telah menyarankan adanya Mata Kuliah baru yang disebut Akuntansi Keindonesiaan di level S1 untuk mengaksikan wacana penginternalisasian Pancasila kedalam ranah akuntansi. Konsekuensi lanjutannya masih dalam Mulawarman (2013) adalah pada pengevaluasian Standar Pendidikan Akuntansi Indonesia (SPAI) yang kemudian menjadi kurikulum, bahan ajar, standarkompetensi, kompetensi dasar, outcome peserta didik serta kriteria dosen dari Pendidikan Akuntansi nasional ke depan.

Seperti yang dikatakan Suwardjono (2008) bahwa akuntansi yang dipraktekan dalam suatu wilayah negara sebenarnya tidak terjadi begitu saja secara alamiah, akan tetapi sengaja dirancang dan dikembangkan untuk mencapai tujuan tertentu. Makadaripada itu, tidak heran jika bila struktur dan praktik akuntansi akan berbeda antara negara yang satu dengan negara yang lainnya. Melalui pernyataan Suwardjono diatas, maka pemakaan ulang kata "stakeholders" akuntansi berbasis pancasila, perlu dirangkai kedalam bentuk teori sehingga menghasilkan teori akuntansi yang baik dan sehat. Dengan demikian akan menuntun dan mengarahkan masyarakat Indonesia dalam menyelesaikan masalah akuntansi dengan baik dan sehat pula. Berikut gambaran proses yang ada dipikiran penulis agar wacana teori pemakaan ulang kata "stakeholders" akuntansi berbasis pancasila menjadi aksi.

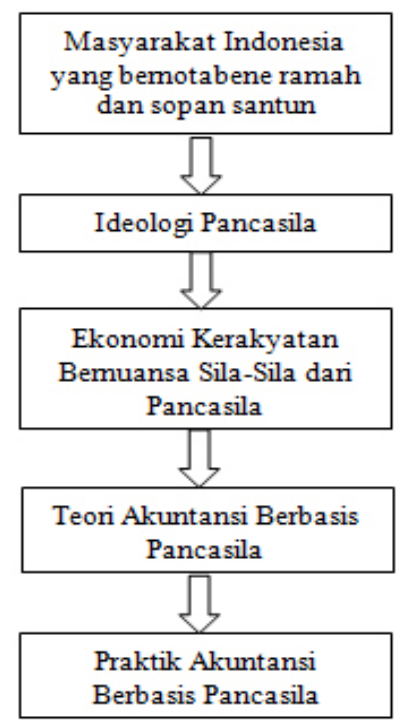

\section{Gambar 1. Proses Terjadinya Praktek Akuntansi Berbasis Pancasila \\ Sumber: Adopsian dari ide Harahap (2013)}

Dampaknya secara langsung akan berelevansi dengan hadirnya praktik akuntansi berbasis pancasila dilingkungan akuntan, hadirnya mata kuliah baru yakni akuntansi berbasis pancasila di dunia perkuliahan, sehingga sistem tatanan 
akuntansi Indonesia yang sekarang mengadopsi dari negara luar, sedikit demi sedikit mulai tereduksi kemudian beralih ke sistem akuntansi yang berlandaskan Pancasila.

Berdasarkan Gambar 1 juga dapat diharapkan setiap entitas tidak akan memiliki pola pikir untuk mencari keuntungan sebesarsebesarnya yang diukur dari aspek keuangan saja (kuantitatif). Lebih jauh, dengan sistem akuntansi berbasis pancasila akan membantu setiap entitas untuk sadar akan nilai-nilai kualitatif sehingga mereka akan berusaha memenuhi aspek pertanggungjawaban berdasarkan unsur humanis. Kemudian, perwujudan masing-masing dari sila pancasila yang memiliki unsur-unsur (butirbutir pancasila) yang saling terkait dan tidak dapat dipisahkan tentunya akan berbeda dengan unsur maskulinitas dalam definisi akuntansi yang berbasis pada kapitalisme yang masih berfokus pada konsep laba dan kapitalisasi modal.

Melalui sila pertama yakni Ketuhanan Yang Maha Esa, pemakaan ulang kata "stakeholders" akan menitik beratkan Tuhan sebagai pemilik tunggal dan mutlak atas seluruh isi alam semesta tanpa terkecuali. Hal ini tentu berbeda dengan pemaknaan ulang kata stakeholders yang merupakan turunan dari konsep proprietary theory atau entity theory yang mengutamakan pemilik modal sebagai pemilik tunggal. Sila pertama ini juga mengajarkan kita untuk bersyukur atas nikmat yang telah diberikan Tuhan. Selain itu, melalui sila ini kita menyadari bahwa sebenarnya semua manusia adalah seorang khalifah di muka bumi ini yang kemudian harus mempertanggungjawabkan segala kegiatannya kepada Tuhan.

Kedua, pemaknaan ulang kata "stakeholders" yang berkemanusian yang adil dan beradab. Secara seksama, kita telah mengetahui bahwa manusia ialah makhluk Tuhan yang paling sempurna yang ketika dilahirkan telah diberikan amanah untuk menjadi pemimpin yang baik. Menjadi pemimpin yang baik tentunya harus dibarengi dengan sikap yang adil dan beradab. Diharapkan dengan silakedua ini, pemakaan ulang kata "stakeholders" dapat berjalan dan diartikan dengan penuh kehormanisan yang dibungkus dengan nilai peradaban, sopan santun, dan saling menghargai. Proses memanusiakan manusia pun terbentuk dengan sendirinya. Alhasil, melalui sila kedua ini nilai-nilai dari perilaku hidup orang barat yakni liberalisme dan kapitalisme sedikit demi sedikit akan mengalami proses reduksi.

Persatuan Indonesia sebagai bunyi dari sila ketiga, memberikan gambaran kepada kita bahwa arti dari kepemilikan ialah kepemilikan publik yang berasal dari terjemahan kata "persatuan." Ketika sekelompok orang telah menyatakan sepakat untuk bersatu, maka tidak ada lagi yang namanya kepentingan pribadi, yang ada hanyalah kepentingan bersama guna menuju tujuan bersama yang telah ditetapkan. Jadi dapat kita simpulkan, melalui sila ketiga, arti dari kepemilikan yang semula hanya diperuntukkan kepada para pemodal dapat kita ubah menjadi "kepemilikan ialah milik bersama dan diperuntukkan secara bersama tanpa ada perbedaan suku, gender, ras, bahasa, dll).

Sila keempat, dapat memberikan warna baru pada pemaknaan ulang kata "stakeholders" yakni pemaknaan ulang kata stakeholders yang berwatak kerakyatan yang mengandung nilai kekeluargaan. Watak kerakyatan dalam hal ini dapat kita analogikan sebagai adanya proses sinergisitas dalam mengabdi, bekarya, dan berdidikasi tinggi untuk negeri. Artinya, dengan pemaknaan ulang kata stakeholders para perusahaan akan melakukan sinergisitas dengan warga sekitar untuk menuju proses pengabdian kepada negaranya. Sehingga tidak ada kalimat "mencari laba sebesar-besarnya dengan pengorbanan sekecil-kecilnya." Kalimat ini akan tergantikan dengan kalimat yang berbunyi "bekorban untuk negara sebesar-besarnya dengan harapan dibalas sekecil-kecilnya". Melalui sila keempat ini diharapkan adanya peningkatan derajat kemanusiaan melalui semangat kekeluargaan.

Pemaknaan ulang kata "stakeholders" yang berkeadilan sosial bagi seluruh rakyat Indonesia, akan menggiring masyarakat untuk memahami kembali sifat cinta dan kasih dalam "diri sistem akuntansi." Ketika sifat cinta dan kasih ini telah mencapai angka yang maksimal, 
kesejahteraan hidup dalam negara akan dirasakan sebagai bonus karena telah memiliki sifat kecintaan dan kasih sayang antar sesame manusia. Alhasil, perusahaan yang dulunya melakukan kegiatan operasi didasari oleh "kuantitas laba" kini tereduksi dan digantikan dengan ada kesadaran untuk mencari kepuasan batin karena telah memberikan cinta dan kasih antar sesama sehingga akan adanya keseimbangan antara kepuasan batin dan rohani dalam diri manusia.

Melalui kelima pemaknaan ulang kata stakeholders yang telah dipaparkan diatas, akhirnya pemaknaan ulang kata "stakeholders" berperspektif pancasila adalah menyadari Tuhan sebagai pemilik tunggal sehingga akan berusaha untuk menjadi karakter manusia yang good character yang kemudian memiliki semangat yang tinggi untuk bersatu dibawah payung nilai kekeluargaan guna menuju konsep keadilan yang bercirikhaskan cinta dan kasih yang kemudian juga tidak akan melupakan makhluk Tuhan yang lain yakni lingkungan yang telah memberikan sumbangsih.

Melalui butir-butir pancasila yang mengandung nilai spiritual, nilai kemanusian, nilai persatuan, nilai kebijaksanaan, dan nilai keadilan dalam memaknai ulang kata stakeholder menjadi representasi perwujudan sifat altruistik Pancasila guna menutupi egoime, private, dan materelialisme. Nilai spiritual dan kebijaksanaan adalah bagian dari sifat "cinta" yang merupakan karakter tuhan dalam membawa atau mewujudkan kedamaian. Sifat cinta inilah yang dapat dipercayai dapat mengeliminasi destruksi yang ditimbulkan oleh akuntansi modernisme, karena cinta mampu membuka jalan sekaligus tujuan. Melalui cinta seseorang biasanya akan bekorban guna menyatukan kedua insan. Namun cinta kepada tuhan, akan mengajarkan kepada kita bagaimana cara kita berserah diri kepadanya dan menghancurkan keangkuhan diri. Jadi secara tidak langsung, melalui cinta kepada-Nya kita akan belajar untuk selalu bersyukur dan paling penting ialah menghilangkan rasa egois yang terlalu tinggi, sehingga hal ini akan membantu para akuntan khususnya untuk kembali sadar bahwa ada unsur tuhan yang harus dinomor satukan dalam pembuatan laporan keuangan bukannya unsur kepentingan pemilik modal.

Kemudian, nilai kemanusian, nilai persatuan, dan nilai keadilan ialah bagian dari sifat "kasih". Kasih atau bisa kita sebut dengan mengasihi ialah suatu sikap dimana adanya rasa iba terhadap suatu lingkungan atau manusia. Melalui sifat kasih, kita akan terdorong untuk lebih memahami arti dari sebuah kehumanisan. Sifat kasih yang kemudian disandarkan dengan gotong royong, peduli akan sesama, dan saling bertenggang rasa, akan menciptakan lingkungan masyarakat madani yang humanis dan beradab.

\section{Tabel 3. Pemaknaan Ulang Kata Stakeholder}

\begin{tabular}{cl}
\hline Sila & \multicolumn{1}{c}{ Pemaknaan Ulang Kata Stakeholder } \\
\hline I & $\begin{array}{l}\text { Konsep Stakeholder yang Berketuhanan adalah mengakui Tuhan sebagai pemilik hak tunggal dan hak } \\
\text { mutlak atas segala sesuatu yang ada di alam semesta ini. }\end{array}$ \\
II $\quad \begin{array}{l}\text { Konsep Stakeholder yang Berkemanusiaan adalah mengakui bahwa manusia memiliki hak } \\
\text { kepemilikan atas suatu objek menurut dasar Ketuhanan melalui proses "memanusiakan manusia" tanpa } \\
\text { mengindahkan faktor lingkungan }\end{array}$ \\
III $\quad \begin{array}{l}\text { Konsep Stakeholder yang bersatu adalah mengakui bahwa manusia memiliki hak kepemilikikan atas } \\
\text { suatu objek guna mencapai persaudaraan tanpa mengindahkan faktor lingkungan }\end{array}$ \\
Konsep Stakeholder yang berkerakyatan adalah mengakui bahwa manusia memiliki hak kepemilikikan \\
$\quad \begin{array}{l}\text { atas suatu objek guna mengangkat derajat rakyatdengan semangat kekeluargaan tanpa mengindahkan } \\
\text { faktor lingkungan } \\
\text { K }\end{array}$ \\
$\begin{array}{l}\text { Konsep Stakeholder yang berkeadilan adalah mengakui bahwa manusia memiliki hak kepemilikikan } \\
\text { lingkungan }\end{array}$
\end{tabular}


Jika akuntansi ditanamkan sifat kasih, ada kemungkinan pemakaan ulang kata stakeholders atau entitas diubah pemaknaannya dengan sudut pandang yang lebih "memanusiakan manusia".

Melalui kelima pemaknaan ulang kata stakeholders yang telah dipaparkan di atas, akhirnya pemaknaan ulang kata stakeholders berbasis Pancasila adalah menyadari Tuhan sebagai pemilik tunggal. Manusia (baca: akuntan) oleh karenanya akan berusaha untuk menjadi karakter manusia dengan good character yang kemudian memiliki semangat yang tinggi untuk bersatu di bawah payung nilai kekeluargaan guna menuju konsep keadilan yang bercirikhaskan cinta dan kasih yang kemudian juga tidak akan melupakan makhluk tuhan yang lain yakni lingkungan yang telah memberikan sumbangsih.

Melalui butir-butir pancasila yang mengandung nilai spiritual, nilai kemanusian, nilai persatuan, nilai kebijaksanaan, dan nilai keadilan dalam memaknai ulang kata stakeholder menjadi representasi perwujudan sifat altruistik berbasis pancasila guna menghilangkan sifat egoisme dan materialisme. Nilai spiritual dan kebijaksanaan adalah bagian dari sifat "cinta" yang merupakan karakter tuhan dalam membawa atau mewujudkan kedamaian. Sifat cinta inilah yang dapat dipercayai dapat mengeliminasi destruksi yang ditimbulkan oleh akuntansi modernisme, karena cinta mampu membuka jalan sekaligus tujuan. Melalui cinta seseorang biasanya akan bekorban guna menyatukan kedua insan. Namun cinta kepada Tuhan, akan mengajarkan kepada kita bagaimana cara kita berserah diri kepadanya dan menghancurkan keangkuhan diri. Jadi secara tidak langsung, melalui cinta kepada-Nya kita akan belajar untuk selalu bersyukur dan paling penting ialah menghilangkan rasa egois yang terlalu tinggi, sehingga hal ini akan membantu para akuntan khususnya untuk kembali sadar bahwa ada unsur tuhan yang harus dinomor satukan dalam pembuatan laporan keuangan bukannya unsur kepentingan pemilik modal.

Nilai kemanusian, nilai persatuan, dan nilai keadilan ialah bagian dari sifat "kasih". Kasih atau bisa kita sebut dengan mengasihi ialah suatu sikap dimana adanya rasa iba terhadap suatu lingkungan atau manusia. Melalui sifat kasih, kita akan terdorong untuk lebih memahami arti dari sebuah kehumanisan. Sifat kasih yang kemudian disandarkan dengan gotong royong, peduli akan sesama, dan saling bertenggang rasa, akan menciptakan lingkungan masyarakat madani yang humanis dan beradab. Jika akuntansi ditanamkan sifat kasih, ada kemungkinan pemakaan ulang kata stakeholders atau entitas diubah pemaknaannya dengan sudut pandang yang lebih "memanusiakan manusia".

\section{Penutup}

Pemahaman mengenai akuntansi dapat pula diidentifikasi melalui karakter seseorang, dalam hal ini karakter mahasiswa. Dengan tipe karakter yang berbeda antara ketiga informan, akhirnya penulis pun berhasil mengindentifikasi pemahaman akuntansi yang berbeda-beda. Karakter Dzikri yang cerdas dan selalu mencoba untuk open minded dalam memahami sesuatu membuatnya memahami akuntansi dengan dominasi akal pikiran yang baik. Nita yang sudah saya kenal sebagai seseorang yang religius yang disertai dengan rasa empati dan simpati yang tingg berhasil membuat pola pikir beliau untuk memahami akuntansi melalui kecerdasan spiritual. Annisa adalah mahasiswi yang kritis, idealis, dan supel, hal ini terlihat dari bagaimana cara beliau berogranisasi dan mempraktikkan dalam kehidupan sehari-hari membantu Annisa memahami akuntansi dari sudut kecerdasan emosional yang bernuansa humanis. Melalui perbedaan karakter ini, tidak heran jika penelitian ini akan mengandung nilai-nilai yang berbedabeda dalam mekanai akuntansi. Namun untuk perlu diingat, walaupun perbedaan karakter membuat perbedaan, Dzikri, Nita, dan Annisa masih memiliki mimpi yang sama yaitu bermimpi Indonesia memiliki sistem akuntansi yang keluar dari logosentrisme kapitalisme.

Penulis tidak mempungkiri bila seluruh pemahaman akuntansi informan diperoleh dari pengalamannya selama menjalani proses perkuliahan. Semua informan adalah mahasiswa S1 angkatan 2012 yang saat ini bearti telah 
menginjak semester akhir. Tentunya, melalui proses yang panjang ini yang kemudian dibalut dengan banyaknya mata kuliah yang telah ditempuhnya, maka mereka pun kemungkinan besar akan terdoktrin dan terbrainwash sehingga mereka sudah memahami akuntansi dalam arti yang lebih luas dan tentunya lebih baik pula. Selain dari proses belajar saat kuliah pemahaman akuntansi mereka juga diperoleh dari pengalamanpengalaman mereka dalam menyikapi lingkungan sekitar. Dzikri yang terbiasa dengan lingkungan mahasiswa-mahasiswa Universitas Indonesia yang selalu punya kemauan untuk belajar lebih giat membuatnya memiliki kecerdasan intelektual yang lebih. Nita yang memang dari kecil telah diajarkan untuk menjadi seseorang yang agamais oleh kedua orang tuanya, membuat Nita untuk selalu taat dan patuh akan segala perintah Tuhan. Lalu, Annisa yang sifatnya hobi bersosialisasi dan hobi melakukan kajian-kajian terhadap perkembangan isu-isu lingkungan kampus dan Indonesia, membuatnya menjadi sosok wanita yang sangat idealis dan memiliki kecerdasan emosional yang tinngi. Melalui pengalaman-pengalaman ini diharapkan mereka akan lebih peduli dengan dunia "keakuntansian" sehingga mereka mampu bersifat responsif yang dihiasi dengan sifat solutif untuk menanggapi permasalahan-permasalahan akuntansi yang ada. Harapannya, disinilah nantinya timbul akuntanakuntan yang selalu berjuang untuk bertindak etis.

Pendidik akuntansi mempunyai peranan yang sangat besar dalam membentukcara berpikir mahasiswa dalam memahami akuntansi. Lalu, dapat dikatakan pula pendidik adalah salah satu pameran penting dalam proses belajar mahasiswa selama kuliah artinya akan ada nilai perubahan dalam dunia pendidikan akuntansi apabila adanya kesadaran dari pendidik untuk terlepas dari sekularisasi. Lebih jauh lagi, akan sangat penting bila adanya perhatian lebih lanjut dalam membentuk kecerdasan mahasiswa. Pendidik haruslah memahami bahwa kecerdasan tidak hanya berbicara intelektual saja, namun juga perlu adanya perbincangan masalah emosional dan spiritual sebagai penyeimbang (Mulawarman,
2012). Disamping itu, metode pembelajaran dan paradigma yang digunakan pendidik juga sangat berperan dalam membentuk pemahaman mahasiswa. Oleh karenanya, pendidik harus mempunyai kesadaran bahwa dalam memberikan ilmu kepada mahasiswa harus menggunakan kolaborasi metode dari berbagai macam metode dan paradigma agar dapat tercapainya pendidikan akuntansi yang seimbang yang menjadi kebutuhan masyarakat banyak.

Bisa dikatakan bahwasanya pemahaman akuntansi di Indonesia masih sangat sempit. Hal ini dapat ditunjunkkan melalui pengakuan ketiga informan. Ketiga informan sepakat setidaknya terdiri atas dua kondisi yang mengakibatkan perbedaan dalam proses memaknai akuntansi, yang pertama ialah sebelum mencapai puncak kesadaran, dan yang kedua ialah ketika sudah mencapai puncak kesadaran. Ketika belum mencapai puncak kesadaran, pemikiran mereka terperangkap pada suatu kondisi yang sama. Hal ini dicontohkan pada bentuk pendefinisian ketiga informan melalui kata stakeholder, ketiganya memiliki pandangan yang sama bahwa stakeholder ialah pemangku kepentingan. Namun, ketika adanya proses keterbukaan diri terhadap unsur-unsur lain yang belum melekat di jati diri akuntansi, mereka pun memberikan penjelasan yang beragam tentang kata stakeholder tersebut. Menjadi sangat penting bila, puncak kesadaran seseorang dalam memahami akuntansi perlu dikembangkan, apalagi mengingat perlunya kepekaan dari para masyarakat yang berkecimpungan di dunia akuntansi, untuk lebih menggali lebih dalam jati diri akuntansi di Indonesia.

Jati diri akuntansi inilah yang nantinya menjadi potret praktik akuntansi. Pengadopsian sistem akuntansi yang dilakukan Indonesia dari negara luar, mungkin saja tidak cocok dikarenakan perbedaan budaya yang mendasari kedua negara tersebut. Jika pemahaman akuntansi tidak dikembangkan, maka akan banyak diantara para masyrakata yang berkecimpungan di dunia akuntansi yang tidak sadar bahwa sebenarnya jati diri akuntansi yang mereka gunakan tidak senada dengan kepribadian bangsa mereka. Jika 
dikembalikan kepada ketiga informan, dengan penjelasan yang berbeda-beda namun tetap ada suatu kesimpulan yang sama yakni jati diri "keakuntansian" di Indonesia tidak selaras dengan ideologi Pancasila, karena mengandung nilai keegoisan, private, sangat saintifik, dan sangat materialistis yang bukan perwujudan dari kepribadian bangsa.

Proses penjajahan di era neomodernisme mungkin saja tidak melalui proses gencatan senjata dan tidak pula melalui perang dingin. Penjajahan era neomodernisme telah memasuki aspek baru melalui aspek-aspek berkehidupan negara yang kemudian kita kenal dengan istilah penjajahan ideologi. Masih kentalnya ideologi kapitalis dalam memasuki segala jiwa di aspek kehidupan, membuat runtuhnya kepribadian bangsa yang berlandaskan Pancasila. Tidak terkecualididunia akuntansi. Proses pengadopsian sistem akuntansi dari IASC yang kemudian kita kenal dengan istilah IFRS adalah sedikit bukti penjajahan neoliberalisme tadi. Tidak heran jika ada orang mengatakan, bahwa sistem akuntansi Indonesia ini berada pada panggung kapitalis. Menindaklanjuti masalah ini, diperlukan adanya konsep penyegaran yang harus dilakukan agar konsep kapitalis tidak berlarut-larut menjajah Indonesia. Kali ini penulis ingin memulainya dari sesuatu yang sangat krusial yakni masalah pemaknaan kata stakeholder.

Pemaknaan kata stakeholder menggunakan versi konsep entity theory yang merupakan produk kapitalis menganggap pemangku kepentingan hanyalah berwujud hubungan horizontal. Artinya, stakeholder tidak menggunakan nilai-nilai transendental. Padahal, sebagai makhluk ciptaan-Nya kita telah mengetahui bahwa segala sesuatu harus dipertanggungjawabkan kepada Tuhan. Hal ini tentu berbeda dengan konsep entity theory tadi. Dengan pemahaman bahwa ada sesuatu yang salah pada makna stakeholders, penulis pun mencoba untuk turun tangan dan kemudian berusaha untuk membuat pemaknaan baru tentang kata stakeholder tersebut.

\section{Daftar Rujukan}

Al-Attas, S. M. A. N., Djojosuwarno, K., \& Mahzar, A. (1981). Islam dan Sekularisme. Pustaka.

Bailey, D. (1990). Accounting in the shadow of stalinism. Accounting, Organizations and Society, 15(6), 513-525.

Bakar, O. (1994). Esei-esei tentang Sejarah Filsafat Sains Islam. Bandung: Pustaka Hidayah.

Bakry, Noor MS. 2010. Pendidikan Pancasila. Yogyakarta. Penerbit: Pustaka Pelajar

Bashir, Z. (1986). Towards an Islamic theory of knowledge, part two. Arabia, 74-5.

Riahi-Belkaoui, A. (1999). Value added reporting and research: state of the art. Greenwood Publishing Group.

Bertens, K. (2000). Pengantar Etika Bisnis. Yogyakarta: Penerbit Kanisius.

Bourdieu, P. (2010). Dominasi Maskulin. Terjemahan S.A Herwinarko. Jalasutra. Yogyakarta.

Capra, F. (2007). The Turning Point: Titik Balik Peradaban, Sains, Masyarakat dan Kebangkitan Kebudayaan. Yogyakarta: Penerbit Jejak.

Dhaouadi, M. (1993). Reflections into the spirit of the Islamic corpus of knowledge and the rise of the new science. American Journal of Islamic Social Sciences, 10(2), 153.

Ekasari, Kurnia. (2012). Internalisasi Nilai-Nilai Pancasila dalam Pendidikan Akuntansi. Prosidig Konferensi Nasional Pendidikan Akuntansi Indonesia, Jurusan Akuntansi FEB Universitas Brawijaya \& IAI KAPd.

Flood P.C. 2004. Individualism/Collectivisme, Perceived Task Interpedence and Teamwork Attitudes Among Irish Blue-Collar Employee: A test of the Main and Moderating effects"'. Human Relations, Vol.57. N0. 3. Hal. 347357.

Hadiwinata, Bob Sugeng. 1994. "Theatrum Politicum": Posdmodernisme dan Krisis Kapitalisme Dunia. Kalam. Edisi 1: 23-31. Hamzah, Ardi. 2008. Perbedaan Persepsi Mahasiswa Akuntansi Mengenai Sosiologi 
Kritis, Kreatifitas, dan Mentalitas. Simposium Nasional Akuntansi XI. Pontianak.

Harahap, Sofyan. (2013). Teori Akuntansi (Edisi Revisi). Jakarta: Rajawali Pers.

Hines, Ruth D. (1989). The sociopolitical paradigm in financial accounting research. Accounting, Auditing, and Accountability Journal 2 (1): 52-76.

Indriantoro, N., \& Supomo, B. (2002). Metodologi Penelitian Bisnis: Untuk Akuntansi dan Manajemen. BPFE. Yogyakarta.

J.H. Kaller. (1993). An introduction to Business Ethics. London: Chapman and Hall.

Kamayanti, A. (2012). Cinta: Tindakan Berkesadaran Akuntan (Pendekatan Dialogis Dalam Pendidikan Akuntansi). Simposium Nasional Akuntansi, 15.

Kamayanti, A. (2012). Developing Conscious Accounting Educators: a Theatrical Perspective (Doctoral dissertation, Tesis).

Kam, Vernon. 1990. Accounting Theory. Second edition. New York: John Wiley \& Sons.

Ludigdo, U. (2012). Memaknai Etika Profesi Akuntansi Indonesia Dengan Pancasila. Pidato Pengukuhan Jabatan Guru Besar Fakultas Ekonomi dan Bisnis Universitas Brawijaya. Malang.

Ludigdo, U., \& Kamayanti, A. (2012). Pancasila as Accountant Ethics Imperialism Liberator. World Journal of Social Science, 2(6), 159168.

Lyotard, Jean-Francois. (1994). The Postmodern Condition, In Seidman, Steven (ed). The Postmodern Turn: New Perspectives on Social Science. Cambridge: Cambridge University Press.

Mayper, Alan G, RJ Pavur, BD Merino dan William Hoops. (2005). The Impact of Accounting Education on Ethical Values: An Institutional Perspective. Accounting and the Public Interest. Vol. 55 pp 32-55.

Mulawarman,A. D. (2017). Pendidikan Akuntansi Berbasis Cinta: Lepas dari Hegemoni Korporasi Menuju Pendidikan yang Memberdayakan dan Konsepsi Pembelajaran yang Melampaui. EKUITAS (Jurnal Ekonomi dan Keuangan), 12(2), 142-158.
Mulawarman,A.D. (2008). PendidikanAkuntansi Berbasis Cinta: Lepas dari Hegemoni Korporasi Menuju Pendidikan yang Memberdayakan dan Konsepsi Pembelajaran yang Melampaui. Ekuitas, 12(2), 142-158.

Mulawarman, Aji Dedi.(2009).Akuntansi Syariah Teori, Konsep dan Laporan Keuangan. Jakarta: E Publishing Company.

Mulawarman, Aji Dedi. (2010). Integrasi Paradigma Akuntansi: Refleksi atas Pendekatan Sosiologi dalam Ilmu Akuntansi. Jurnal Akuntansi Multiparadigma. (Volume 1, Nomor 1, April 2010, 161-162).

Mulawarman, Aji Dedi. (2012). Pendidikan Akuntansi Indonesia: Pro Neoliberal atau Pancasila?. Prosidig Konferensi Nasional Pendidikan Akuntansi Indonesia, Jurusan Akuntansi FEB Universitas Brawijaya \& IAI $K A P d$.

Powell, Walter W, and Paul J. Dimaggio. (1991). The New Institutionalism in Organizational Analysis. Chicago: University of Chicago Press.

Ragab, I. (1993). Islamic perspective on theory building in the social sciences. American Journal of Islamic Social Sciences, 10(1), 1.

Rahmat, Muhammad. (2010). Pengungkapan Public Cost and Benefit dalam Perspektif Nilai Murabahah (Cinta). Skripsi. Malang: Program Strata 1 Universitas Brawijaya.

Rasyidin W.(2007). Ilmudan Aplikasi Pendidikan. Bandung: Pedagogiana Press.

Reiter, S. (1997). The Ethics of Care and New Paradigms for Accounting Practice. Accounting, Auditing and Accountability Journal.Vol 10, No 2.p 299-324.

Renton, Dave. (2009). Membongkar Akar Krisis Global. Yogjakarta: Resist Book.

Rorty, Richard (1994). Method, Social Science, and Social Hope. In Seidman, Steven (ed). The Postmodern Turn: New Perspectives on Social Science. Cambridge: Cambridge University Press.

Rosenau, Pauline M. (1992). Post-Modernism and the Social Sciences: Insights, Inroads, and Intrusions. New Jersey: Priceton University Press. 
Salampessy, Z. (2011). Konsep Kepemilikan Dalam Akuntansi Berdasarkan Falsafah Pancasila (Doctoral dissertation, Tesis. Malang: Program Strata 2 Universitas Brawijaya).

Santiko, Bonifasius. (2012). Dekonstruksi Laba Dalam Perspektif Pancasila. Skripsi Strata 1. Malang: Universitas Brawijaya.

Seidman, Steven. (1994). Introduction. In Seidman, Steven (ed). The Postmodern Turn: New Perspectives on Social Science. Cambridge: Cambridge University Press.

Setiabudi, Henry Y. dan Iwan Triyuwono. (2002). Akuntansi Ekuitas dalam Narasi Kapitalisme, Sosialisme dan Islam. Jakarta: Salemba Empat.

Setiawan, Achdiar Redy dan Ari Kamayanti. (2012). Mendobrak Reproduksi Dominasi Maskulinitas dalam Pendidikan Akuntansi: Internalisasi Pancasila dalam Pembelajaran Accounting Fraud. Prosidig Konferensi Nasional Pendidikan Akuntansi Indonesia, Jurusan Akuntansi FEB Universitas Brawijaya \& IAI KAPd.

Skousen, Marx. (2009). Sang Maestro, "TeroriTeori Akuntansi Modern": Sejarah Pemikiran Ekonomi. Jakarta: Media Grup.

Stooner, Freeman, dan Gilbert. 2004. Pengantar Bisnis. Yogjakarta: Graha Ilmu

Sukoharsono, E. G. (2010). Metamorfosis Akuntansi Sosial dan Lingkungan: Mengkonstruksi Akuntansi Sustainabilitas Berdimensi Spiritualitas. Malang: Pidato Pengukuhan Jabatan Guru Besar Fakultas Ekonomi dan Bisnis Universitas Brawijaya.

Suwardjono. (2005). Teori Akuntansi: Perekayasaan Laporan Keuangan (Edisi Ketiga). Yogjakarta: BPPE.

Supratikno, Hendrawan. (2010). Ekonomi Nurani vs Ekonomi Naluri. Jakarta: Yayasan Pustaka Obor.

Sukoharsono, E. G. (2012). Luca Pacioli's Response To Accounting Whereabout: An Imaginary Spiritual Dialogue. Jurnal Akuntansi Multiparadigma. Vol. 3, No. 3, hlm. 457-461.

Triyuwono, Iwan. dan Moh. As'udi. (2001).
Akuntansi Syari'ah; Memformulasikan Konsep Laba dalam Konteks Metafora Zakat. Jakarta: Salemba Empat.

Triyuwono, Iwan. (2006). Akuntansi Syari'ah: Implementasi Nilai keadilan dalam Format Metafora Amanah, Jurnal Akuntansi dan Auditing Indonesia, Vol 4. No1: 1-34.

Triyuwono, Iwan. (2007). Mengangkat "Sing Liyan" untuk Formulasi Nilai Tambah Syariah. Jurnal Akuntansi Multiparadigma. (Volume 1, Nomor 1, April 2010, 161-162).

Triyuwono, Iwan. (2009). Perspektif, Metodologi, dan Teori Akuntansi Syariah. Jakarta: Rajawali Press.

Triyuwono, (2012). Akuntansi Syariah: Perspektif, Metodologi, dan Teori (Edisi Kedua). Jakarta: Rajawali.

Townsley, P. (1998). Social Issues In Fisheries. FAO Fisheries Technical Paper. No. 375. Rome, FAO. 1998. 39p.

Wats, Ross L, and Jerold L. Zimmerman. (1986). Positive Accounting Theory. Englewood Cliiffs: Prentice-Hall, inc.

Yudistira. (2013). Pendidikan Akuntansi Sebagai Pembentuk Kecerdasan Intelektual, Emosional, dan Spritual Mahasiswa Dalam Memahami Akuntansi: Studi Fenomenalogis. Tesis. Tidak terpublikasi. Malang: Universitas Brawijaya 